\title{
Boronic acid pairs for sequential bioconjugation
}

Mary. K. Miller*; Michael J. Swierczynski*; Yuxuan Ding; Zachary. T. Ball

Department of chemistry, Rice University, 6100 Main Street, Bioscience Research

Collaborative, Houston, Texas 77005, United States

Email: zb1@ rice.edu

\section{Supporting Information}

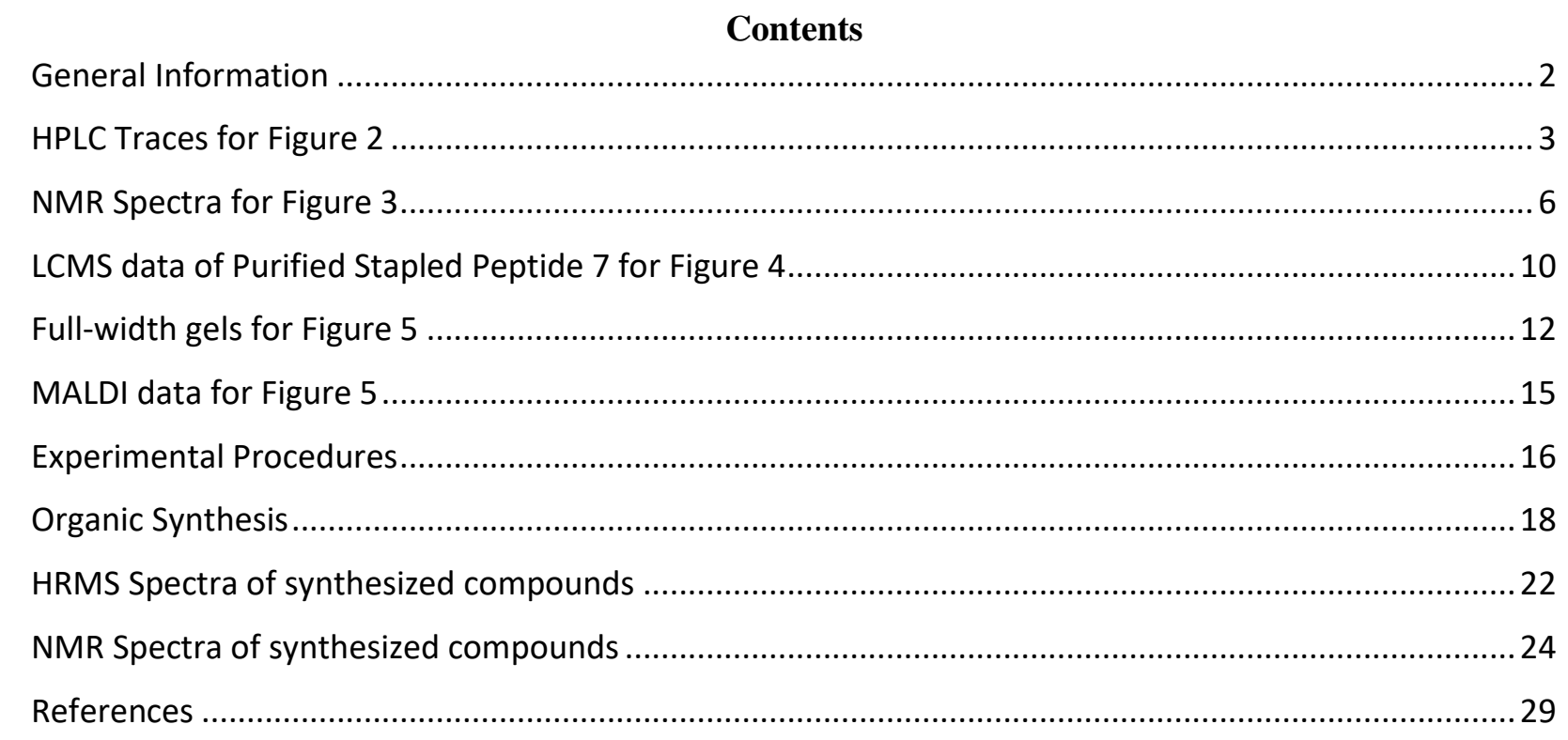




\section{General Information}

All chemicals were purchased from commercial suppliers and used without further purification. Boronic acids 2a-2k and 10 were purchased from Combi-Blocks. Boc-L-Cys-OH 8 was purchased from ChemImpex (\#01341). Size exclusion columns were purchased from GE Healthcare (\#17085101). High-capacity streptavidin agarose resin was purchased from Fisher (\# 20357). T4L(V131C) and sfGFP(S147C) were expressed and purified as previously reported. ${ }^{1}$ pGlu-His-GFP was expressed as previously reported ${ }^{2}$ and purified by organic extraction. ${ }^{3}$ Compound $\mathbf{S 1}$ was synthesized as previously reported. ${ }^{2} \mathrm{~N}$ methylmorpholine (NMM) buffer was prepared by the addition of NMM (TCI, M0370) to MilliQ water. The $\mathrm{pH}$ of the NMM solution was adjusted to the desired $\mathrm{pH}$ by addition of aq $\mathrm{HCl}$. Peptide synthesis was performed according to standard solid phase synthetic protocols using rink amide resin. ${ }^{4}$

\section{Instrumentation}

Reverse-phase HPLC (RP-HPLC) was performed on a Shimadzu CBM-20a instrument with Phenomenex Jupiter $4 \mu$ Proteo 90A ( $250 \mathrm{~mm} \times 4.6 \mathrm{~mm}$ for analytical scale) and Phenomenex Jupiter $4 \mu$ Proteo 90A ( $250 \times 15 \mathrm{~mm}$ for preparative scale) column. The flow rate was $1 \mathrm{~mL} / \mathrm{min}$ for analytical scale and $8 \mathrm{~mL} / \mathrm{min}$ for preparative scale. A gradient of acetonitrile/water with $0.1 \%$ trifluoroacetic acid (TFA) was employed. Compounds were detected by UV detector at $220 \mathrm{~nm}$ and $280 \mathrm{~nm}$.

UPLC was performed on a Waters Acquity UPLC instrument with a Waters UPLC BEH C18 $(2.1 \times 50$ $\mathrm{mm}$ ) column. The flow rate was $1 \mathrm{~mL} / \mathrm{min}$. A gradient of acetonitrile/water with $0.1 \%$ trifluoroacetic acid (TFA) was employed. Compounds were detected by UV detector at $220 \mathrm{~nm}$ and $280 \mathrm{~nm}$.

ESI-MS was conducted on a Bruker Daltonics MicroTOF spectrometer.

MALDI-TOF MS was conducted on Bruker Daltonics Autoflex Speed-MALDI-TOF/TOF spectrometer. Sinapic acid $\left(1 \mu \mathrm{L}, 20 \mathrm{mg} / \mathrm{mL}\right.$ soln in 50:50:0.1 $\left.\mathrm{H}_{2} \mathrm{O} / \mathrm{MeCN} / \mathrm{TFA}\right)$ was spotted on a MALDI plate and dried. An aliquot of protein reaction $(1 \mu \mathrm{L})$ was mixed with equal volume of sinapic acid soln and spotted on dried MALDI plate.

${ }^{1}$ H NMR and ${ }^{13} \mathbf{C}$ NMR spectra were obtained on Bruker AVANCE 600 spectrometer.

Gel imaging was conducted on LAS-4000 imager (Fujifilm). Coomassie-stained gels were imaged with differential in-gel analysis (DIA). 


\section{HPLC Traces for Figure 2}

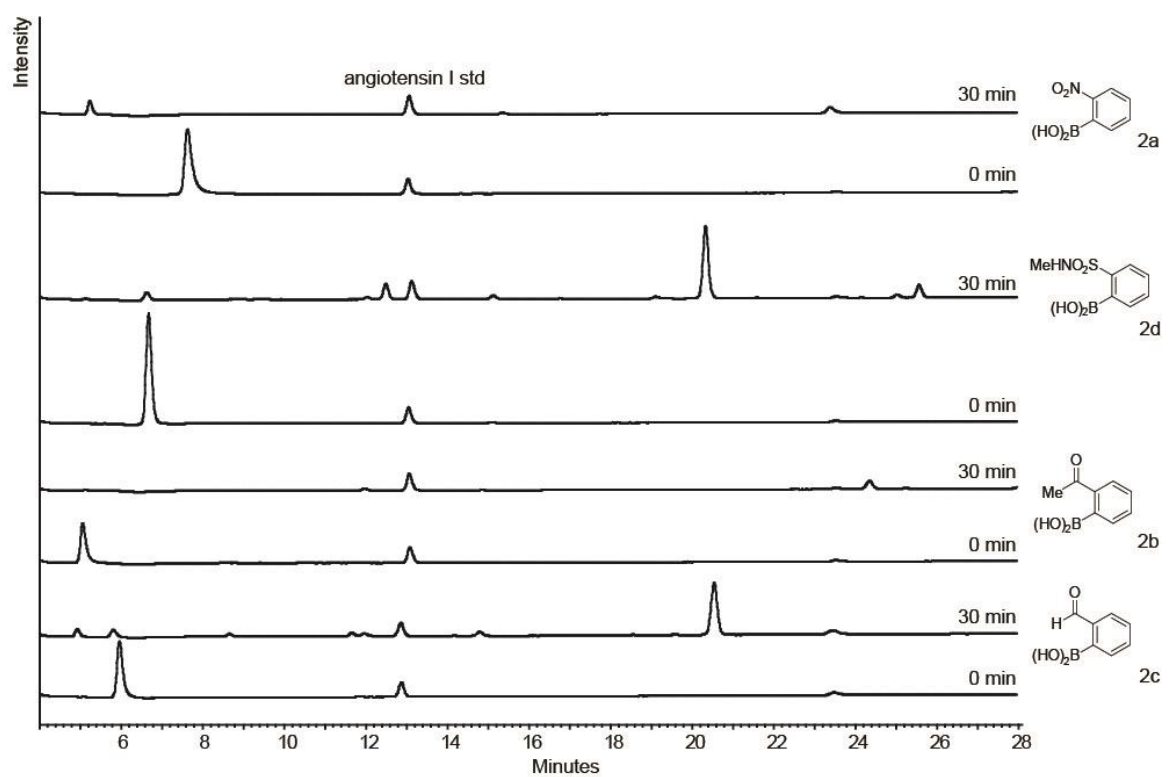

Figure S1. RP-HPLC spectrum of the reaction of $\mathrm{N}$-acetylcysteine with boronic acid reagents and copper(II) at 0 min and $30 \mathrm{~min}$. Angiotensin I was used as an internal standard

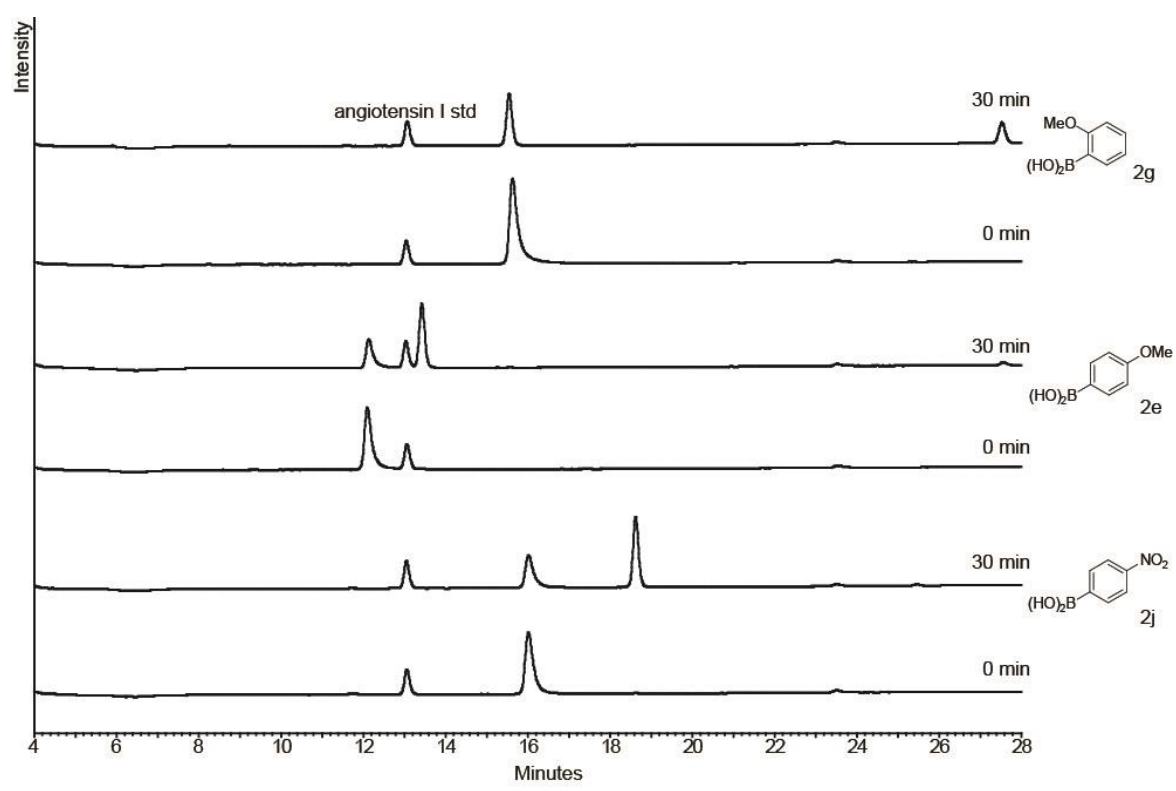

Figure S2. RP-HPLC spectrum of the reaction of $\mathrm{N}$-acetylcysteine with boronic acid reagents and copper(II) at $0 \mathrm{~min}$ and $30 \mathrm{~min}$. Angiotensin I was used as an internal standard 


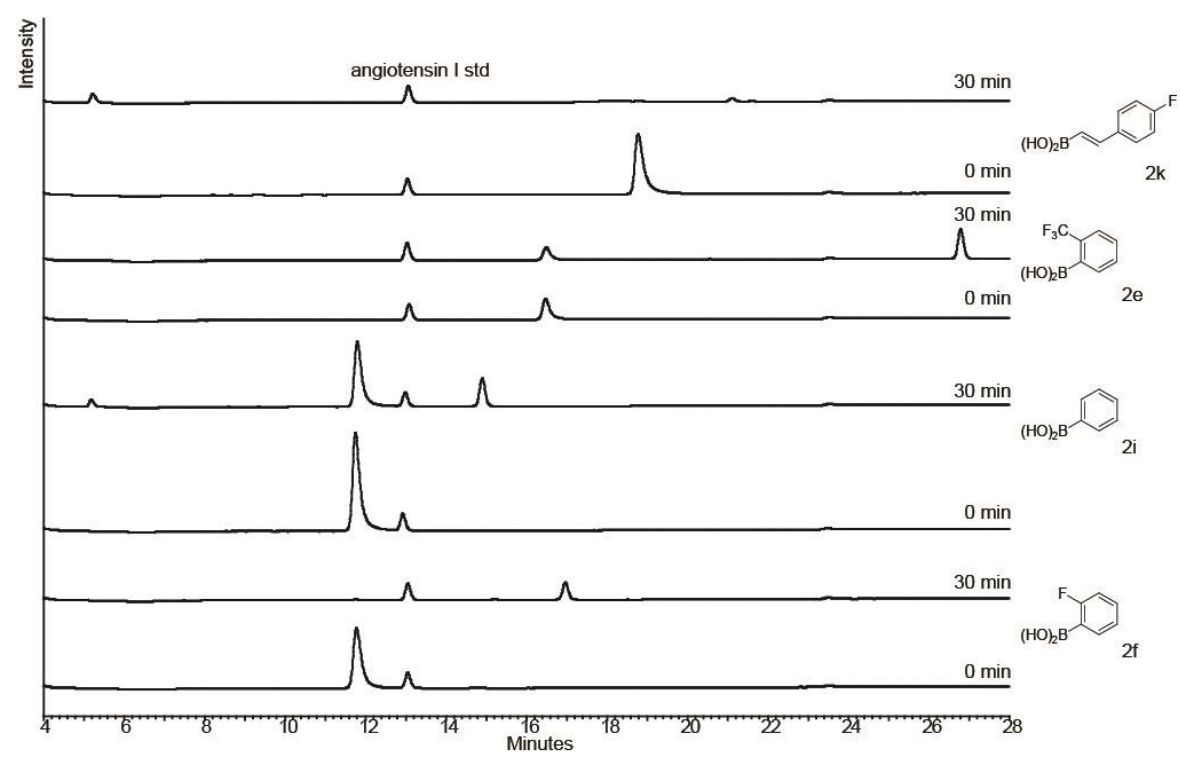

Figure S3. RP-HPLC spectrum of the reaction of $\mathrm{N}$-acetylcysteine with boronic acid reagents and copper(II) at $0 \mathrm{~min}$ and $30 \mathrm{~min}$. Angiotensin I was used as an internal standard

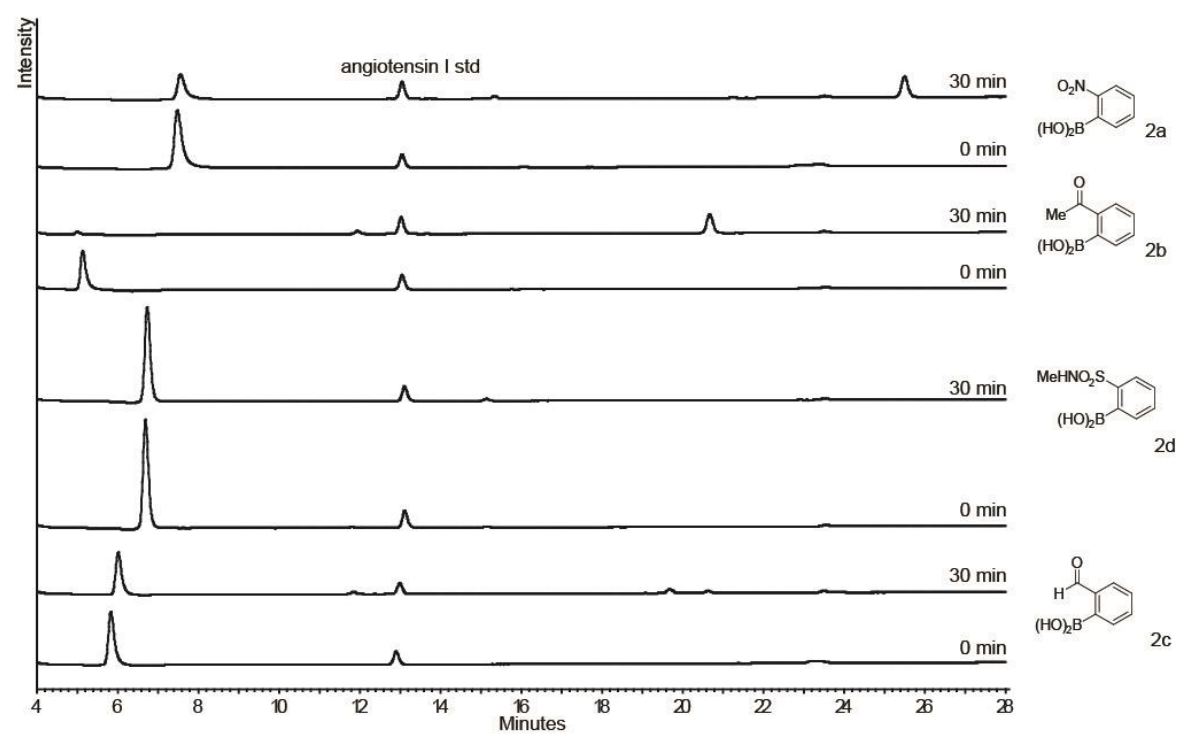

Figure S4. RP-HPLC spectrum of the reaction of $N$-acetylcysteine with boronic acid reagents and nickel(II) at $0 \mathrm{~min}$ and $30 \mathrm{~min}$. Angiotensin I was used as an internal standard 


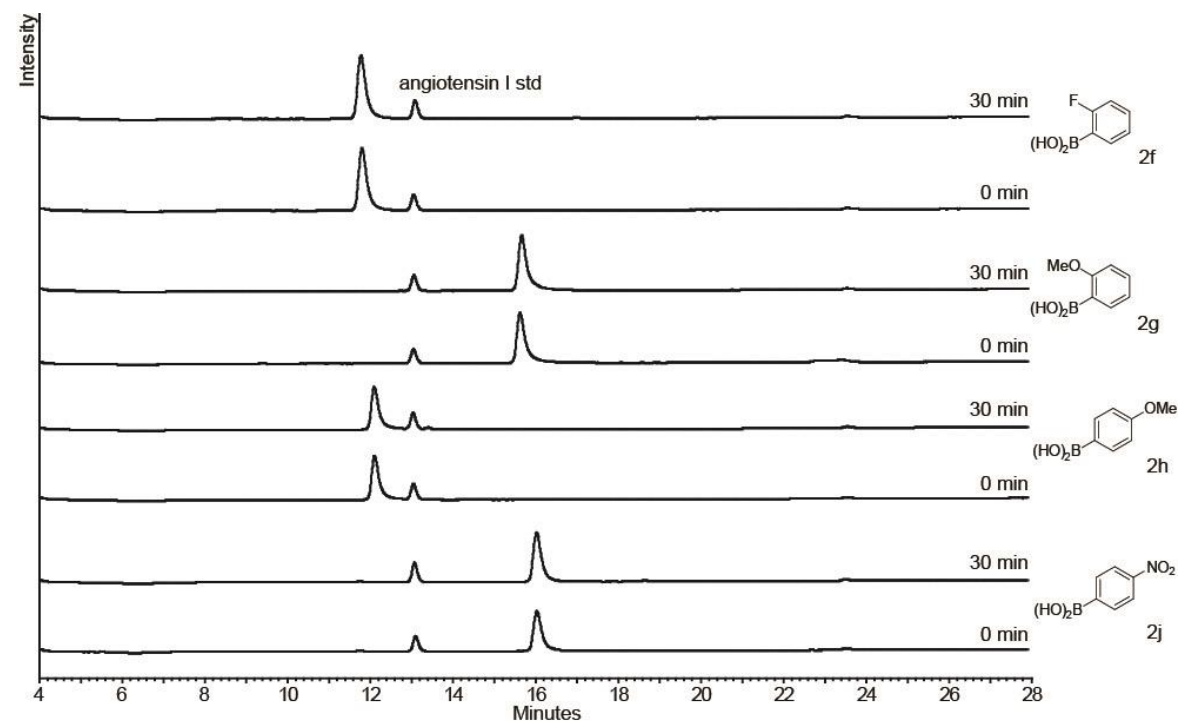

Figure S5. RP-HPLC spectrum of the reaction of $N$-acetylcysteine with boronic acid reagents and nickel(II) at $0 \mathrm{~min}$ and $30 \mathrm{~min}$. Angiotensin I was used as an internal standard

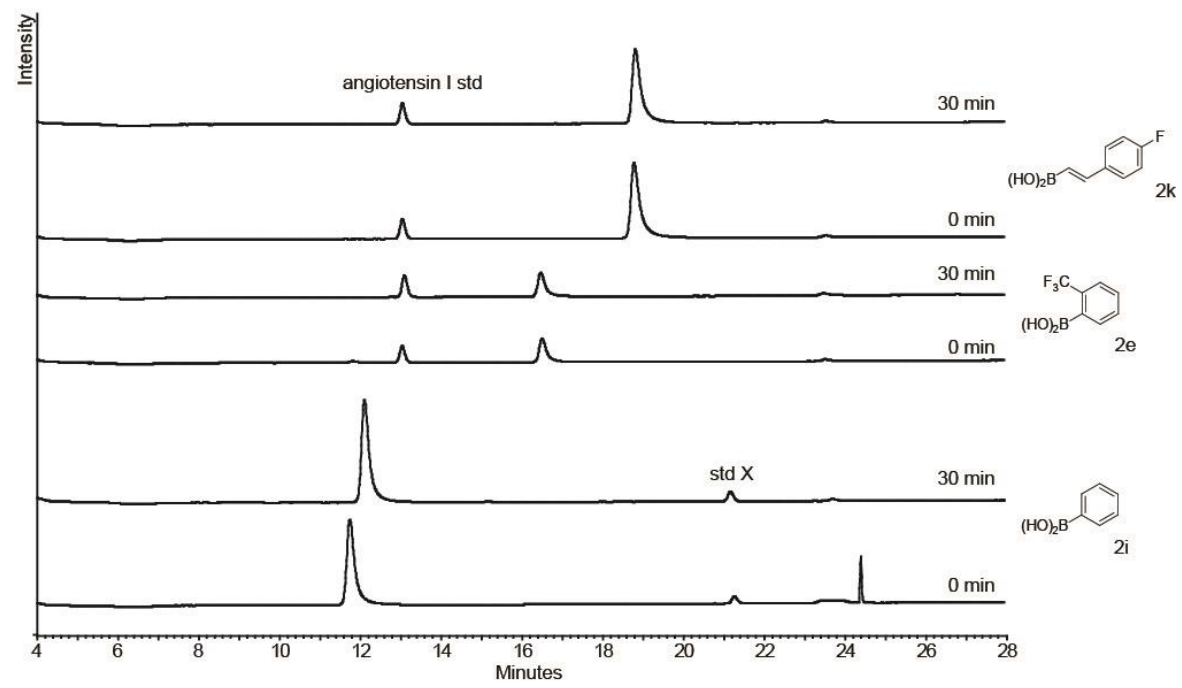

Figure S6. RP-HPLC spectrum of the reaction of $N$-acetylcysteine with boronic acid reagents and nickel(II) at $0 \mathrm{~min}$ and $30 \mathrm{~min}$. Angiotensin I was used as an internal standard 


\section{NMR Spectra for Figure 3}

a)

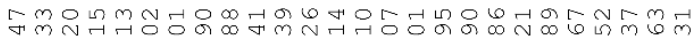

ฟ.

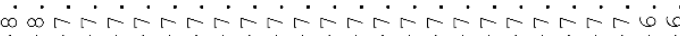

$\longrightarrow$

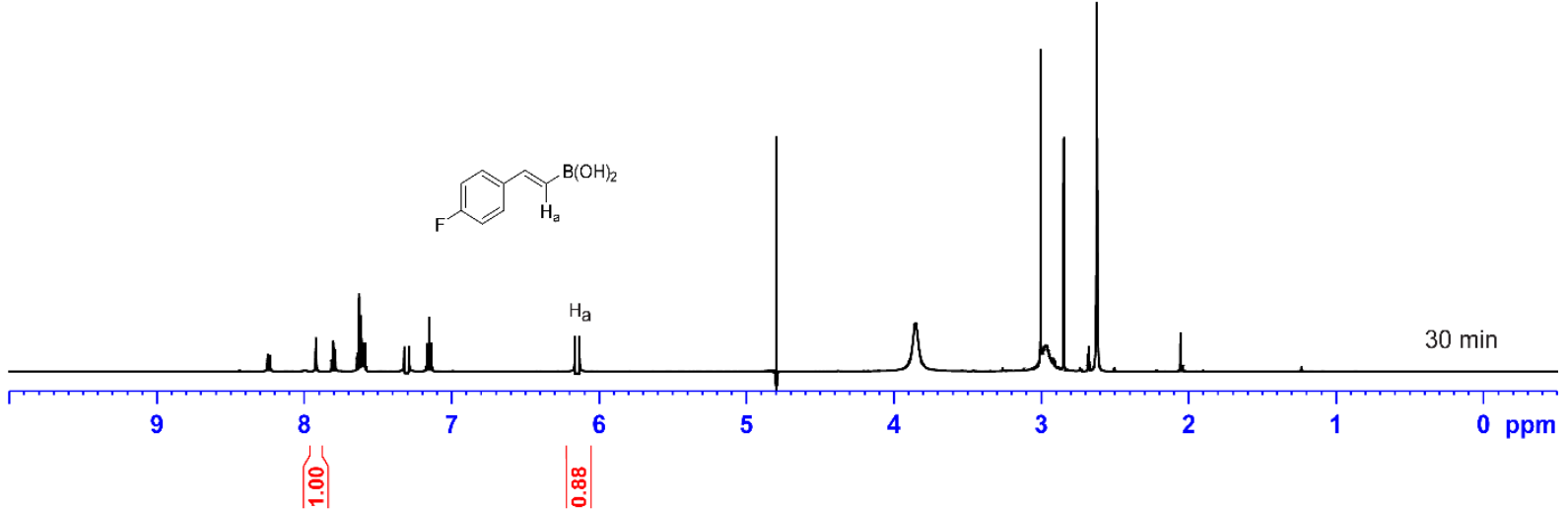

b)
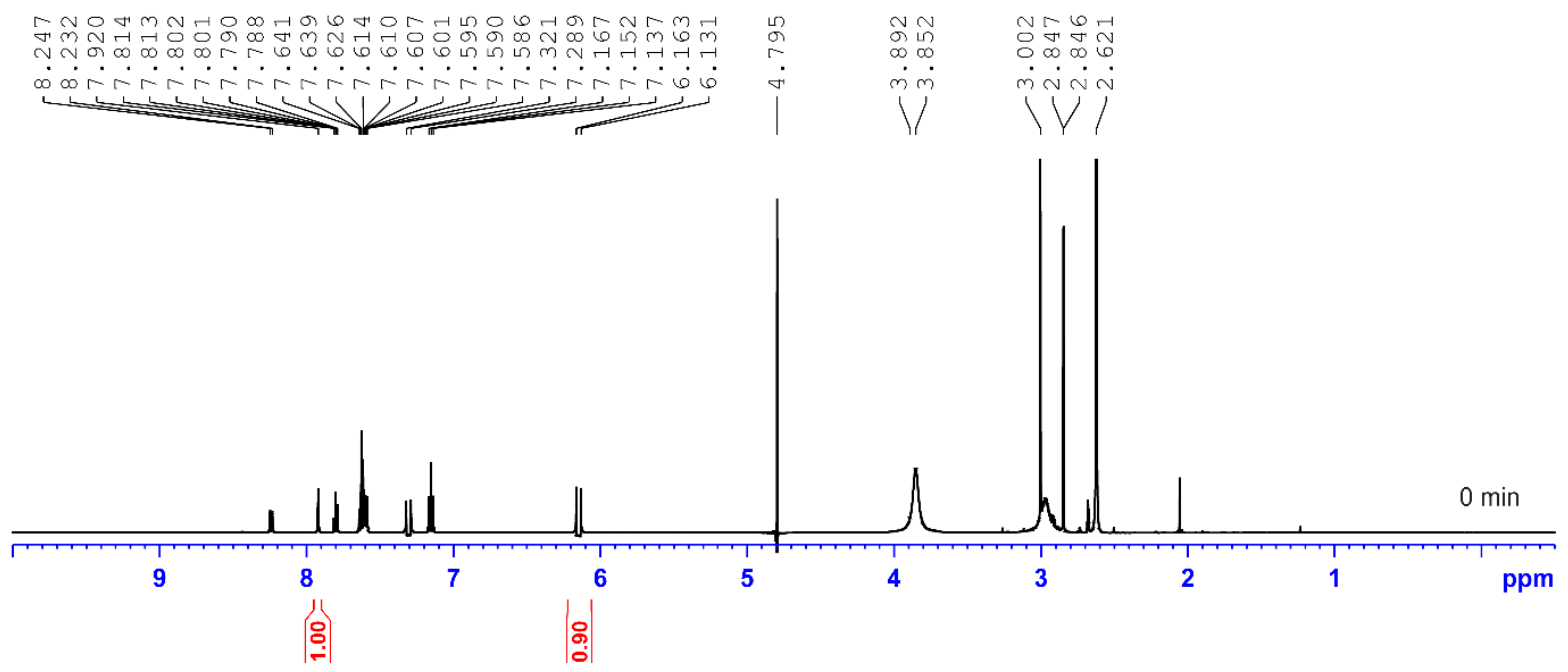

Figure S7. ${ }^{1} \mathrm{H}$ NMR spectra $(600 \mathrm{MHz})$ of the reaction of $\mathrm{N}$-acetylcysteine with $2 \mathbf{a}$ with added boronic acid $2 \mathbf{k}$ after $30 \mathrm{~min}$ (a) or $0 \mathrm{~min}$ (b) with no $\mathrm{Ni}(\mathrm{OAc})_{2}$ added. Boronic acid peaks were calibrated to the DMF internal standard. 
a)
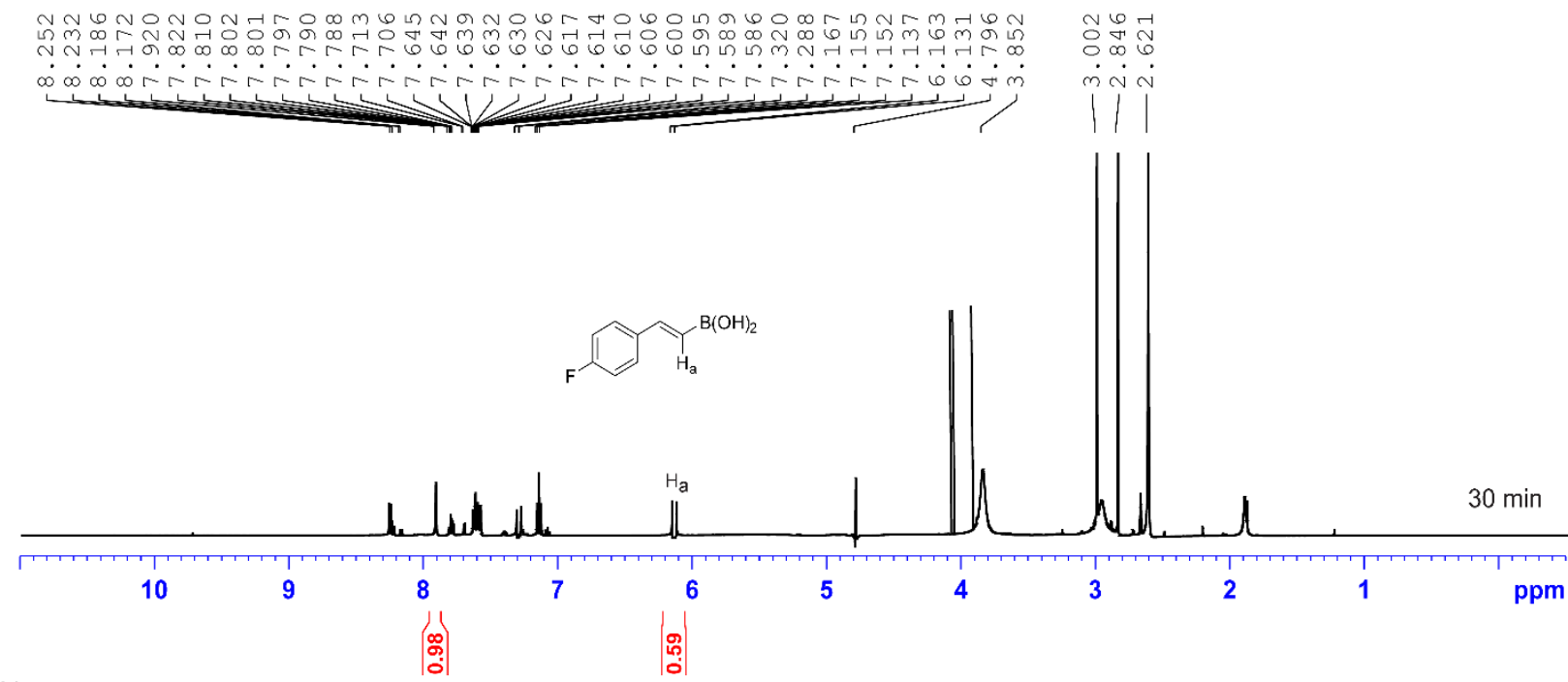

b)
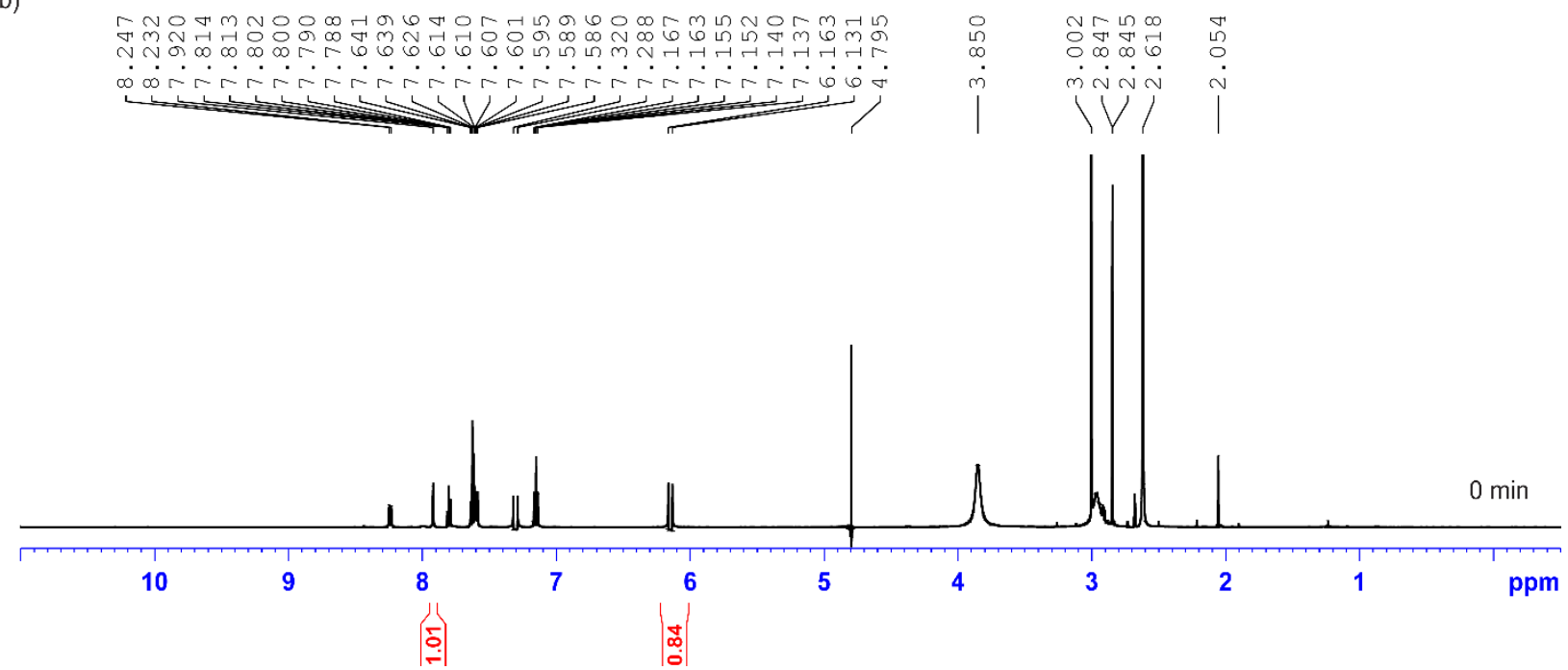

Figure S8. ${ }^{1} \mathrm{H}$ NMR spectra $(600 \mathrm{MHz})$ of the reaction of N-acetylcysteine with 2a with added boronic acid 2k after 30 min (a) or 0 min (b) Boronic acid peaks were calibrated to the DMF internal standard. 
a)

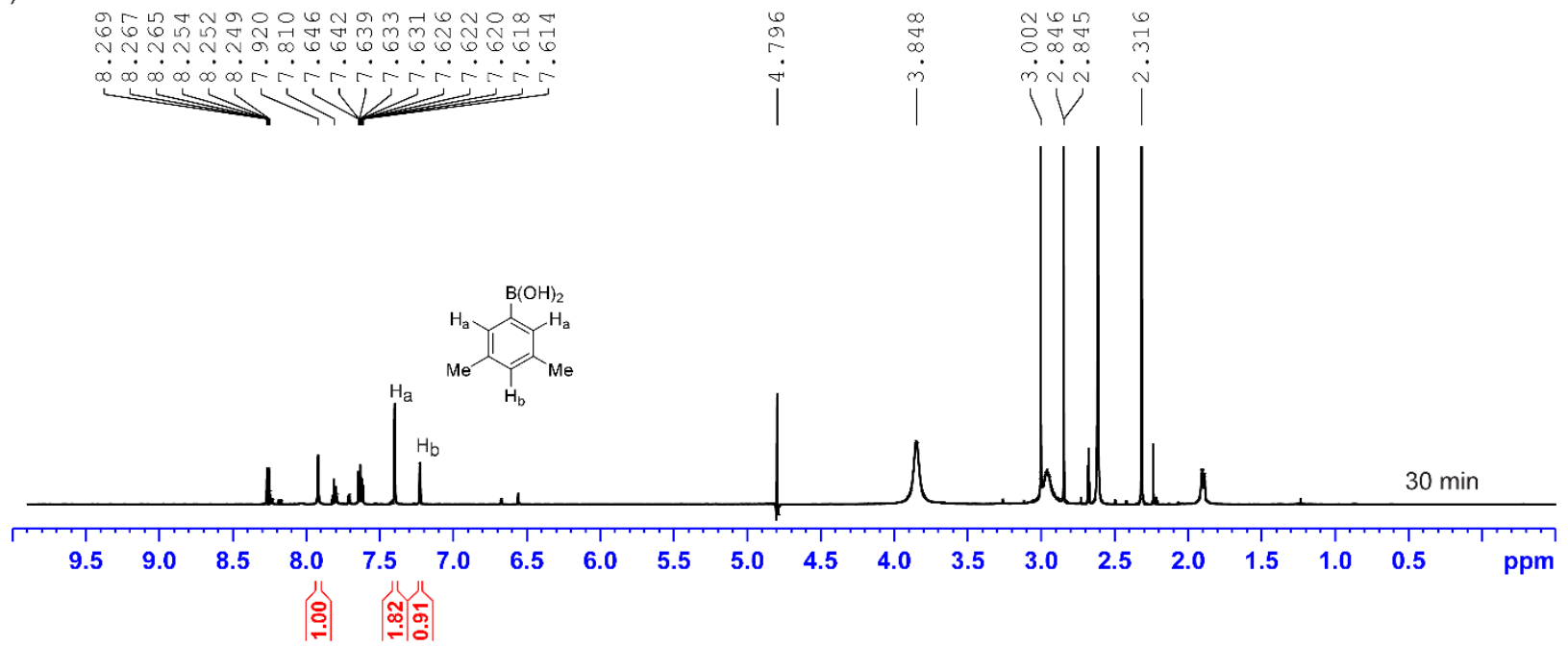

b)
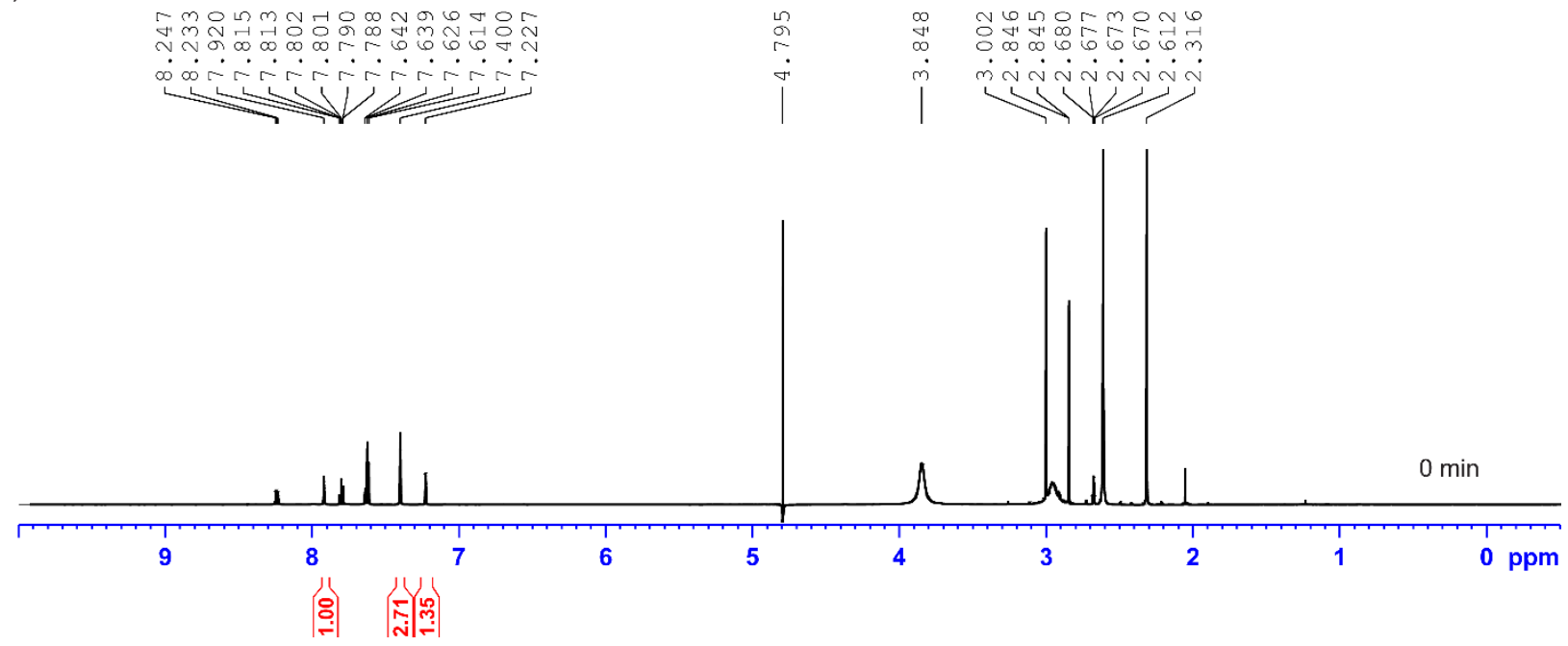

Figure S9. ${ }^{1} \mathrm{H}$ NMR $(600 \mathrm{MHz})$ spectra of the reaction of $\mathrm{N}$-acetylcysteine with $2 \mathbf{a}$ with added boronic acid $2 \mathbf{l}$ after 30 min (a) or 0 min (b). Boronic acid peaks were calibrated to the DMF internal standard. 
a)
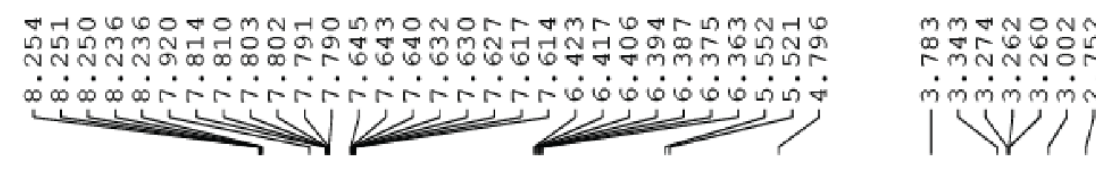

$30 \mathrm{~min}$

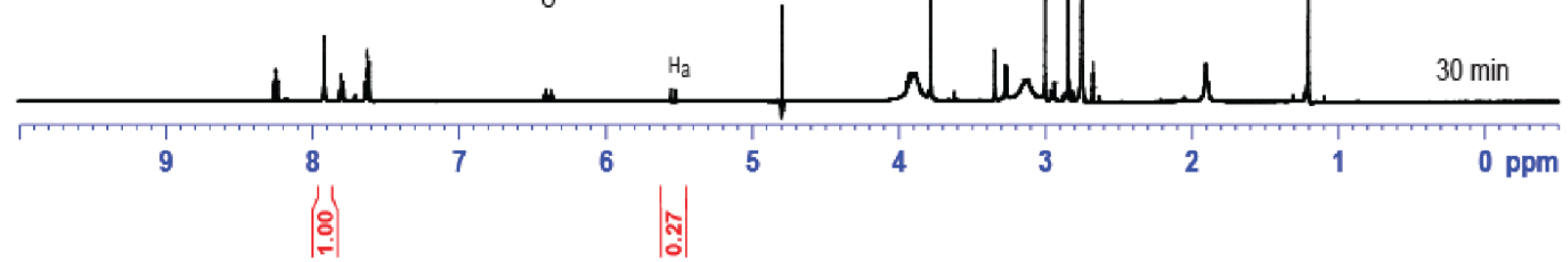

b)

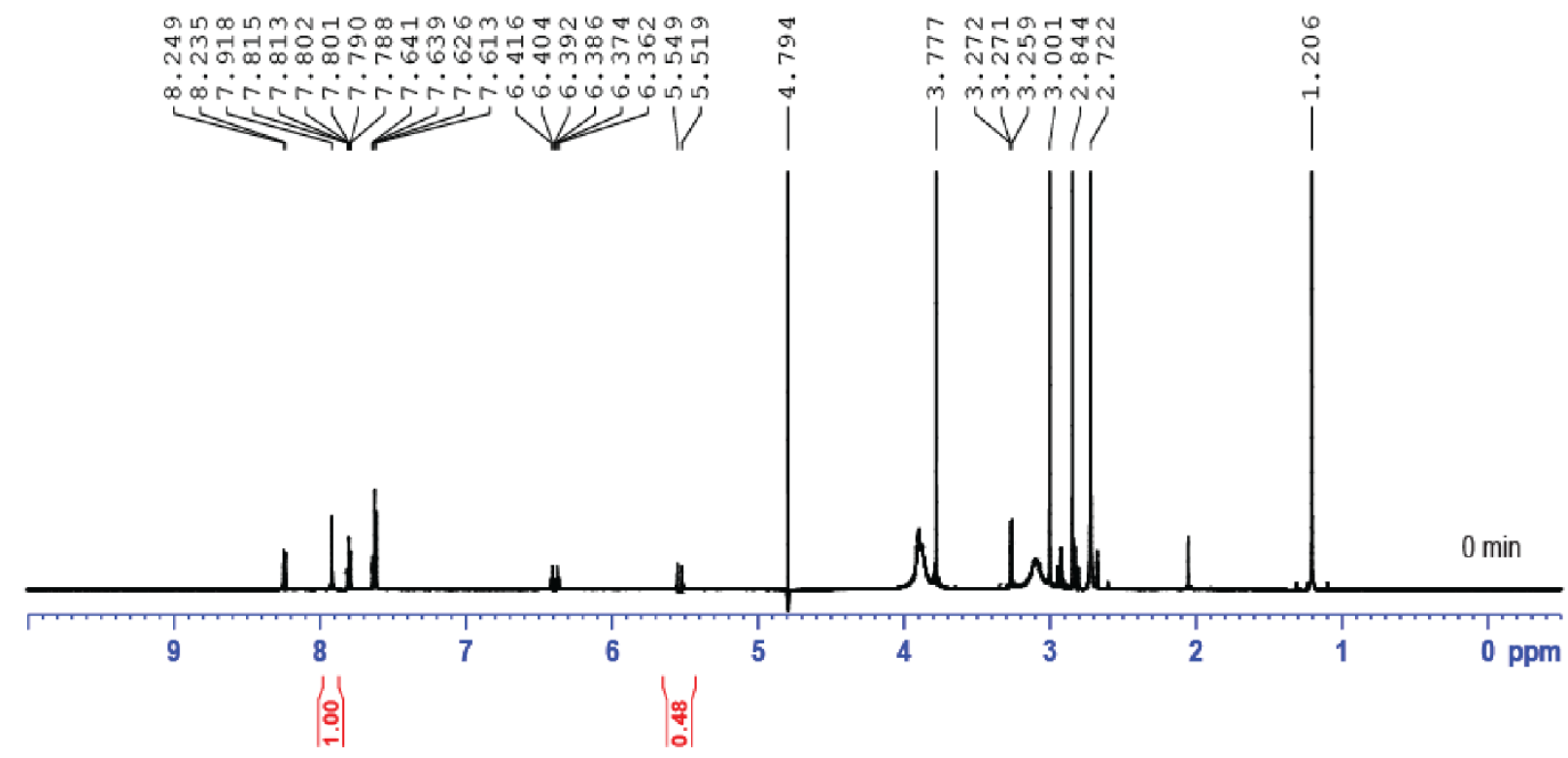

Figure S10. ${ }^{1} \mathrm{H}$ NMR $(600 \mathrm{MHz})$ spectra of the reaction of $\mathrm{N}$-acetylcysteine with $\mathbf{2 a}$ with added boronic acid $\mathbf{2 m}$ after $30 \mathrm{~min}$ (a) or $0 \mathrm{~min}$ (b) with no $\mathrm{Ni}(\mathrm{OAc})_{2}$ added. Boronic acid peaks were calibrated to the DMF internal standard. 


\section{LCMS data of Purified Stapled Peptide 7 for Figure 4}

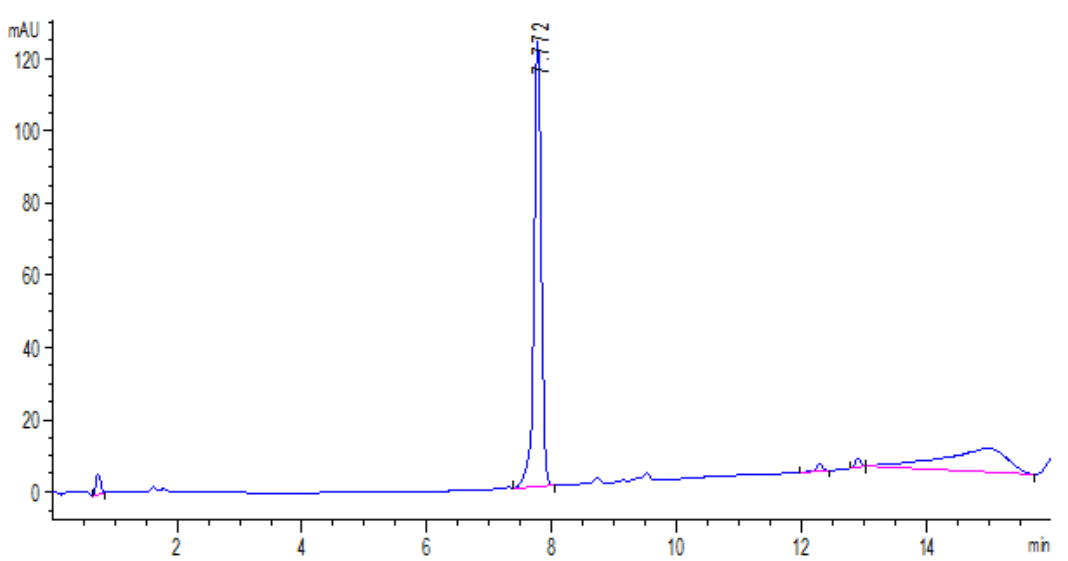

Figure S11. LC-MS chromatogram of the purified stapled peptide 7

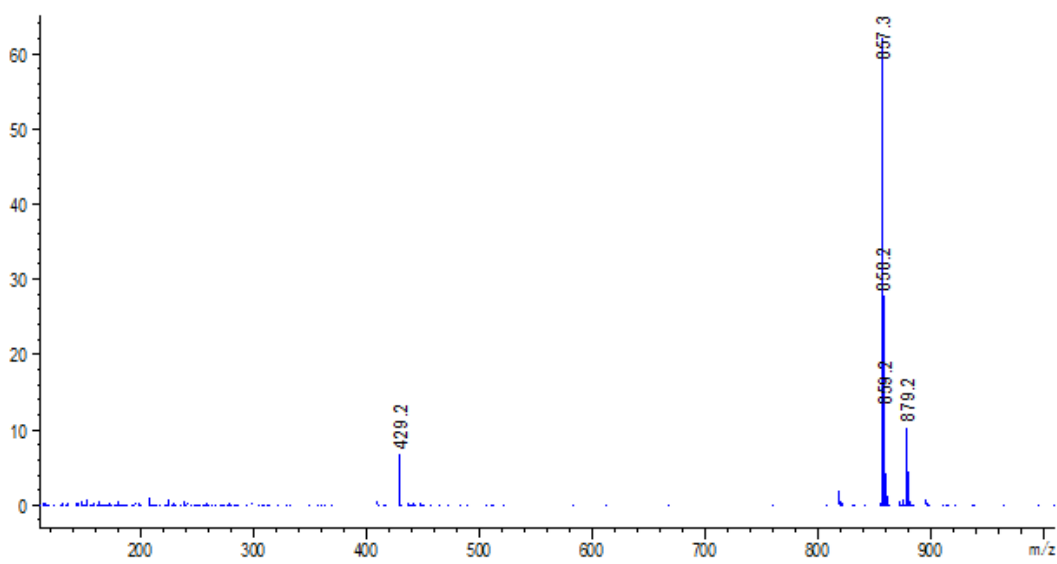

Figure S12. Mass spectrum of the purified stapled peptide 7. $\mathrm{m} / \mathrm{z}=857.3$ corresponds to $[\mathrm{M}+\mathrm{H}]^{+}$ 
a)

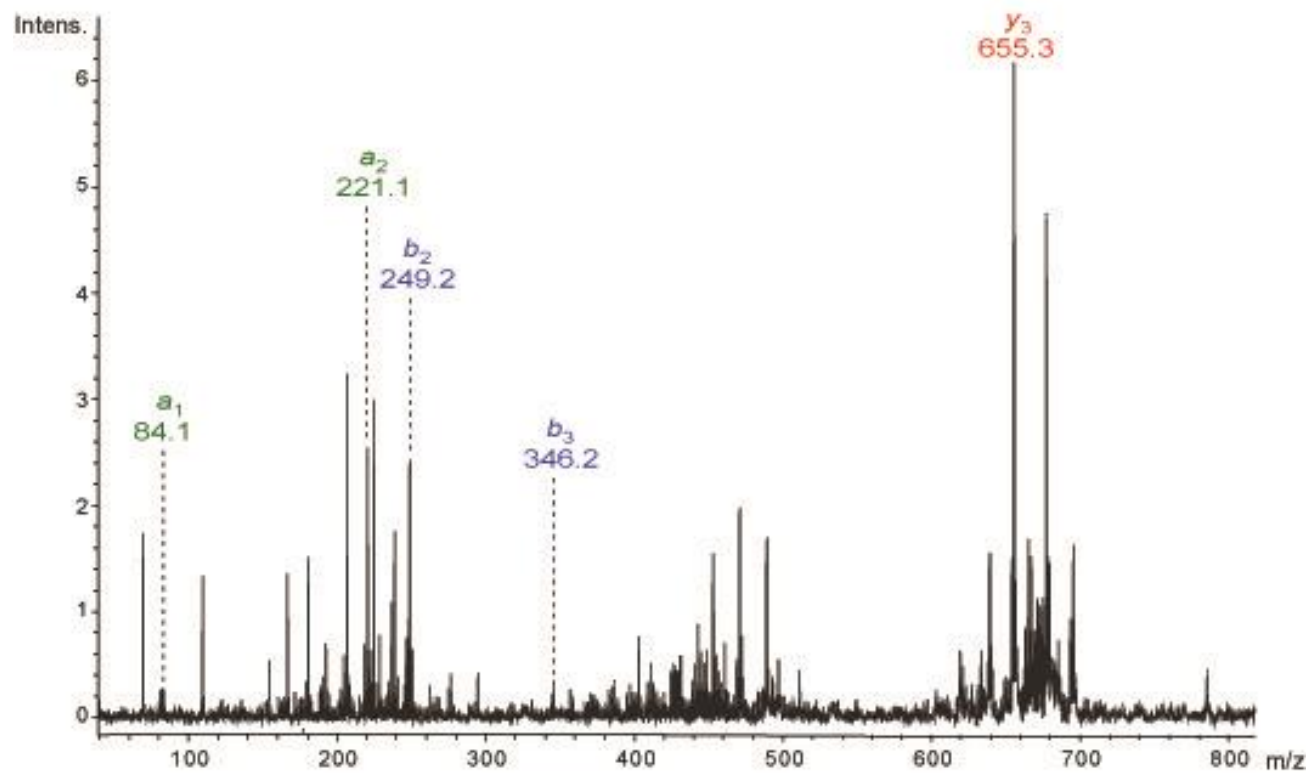

b)

c)
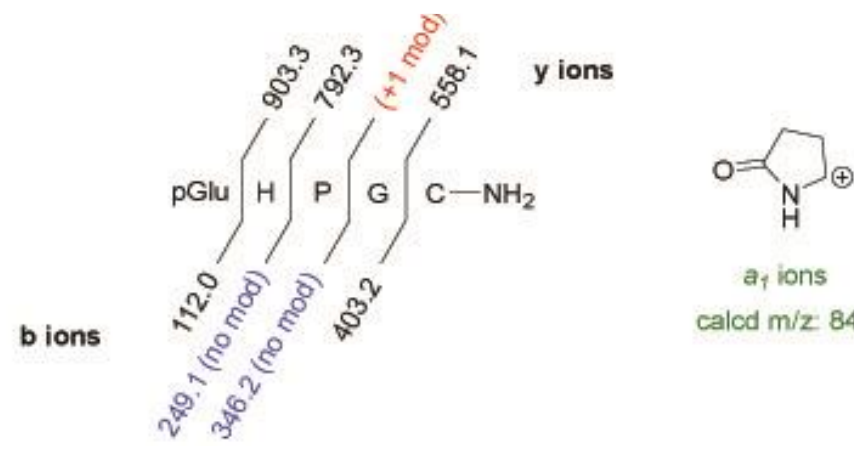

calcd $\mathrm{m} / \mathrm{z}=84.0$

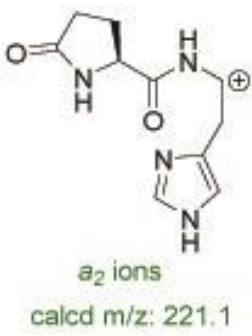

Figure S13. a) MALDI-MS/MS spectrum of the cysteine-modified peptide $\mathbf{6}$ b) Fragmentation ladder showing observed peaks c) Structures and masses of the observed $a_{1}$ and $a_{2}$ ions 


\section{Full-width gels for Figure 5}

T4L conjugation with pGH-biomolecules

a)
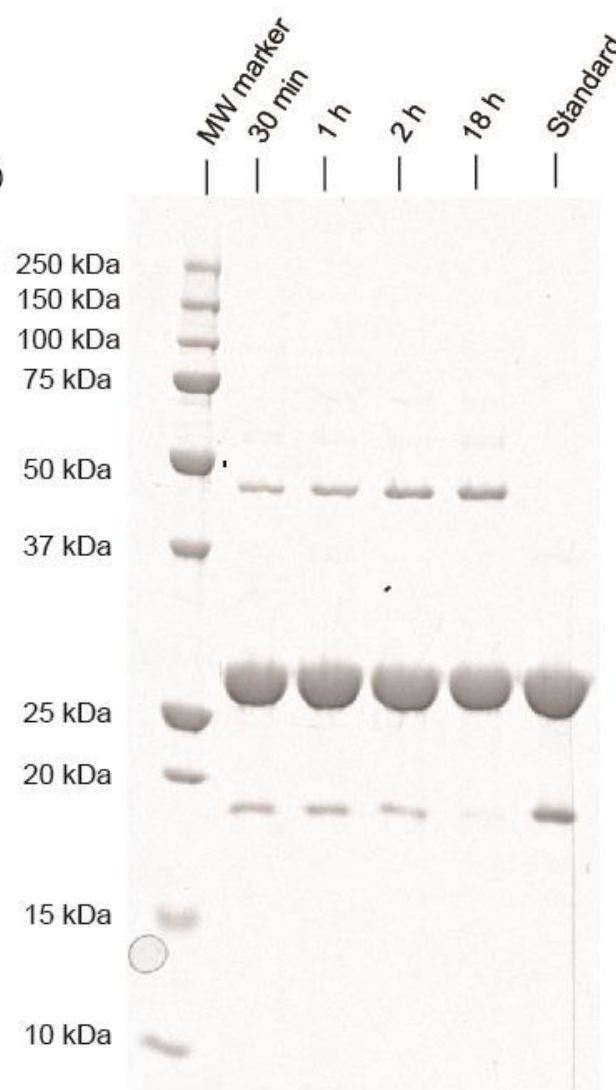

b)
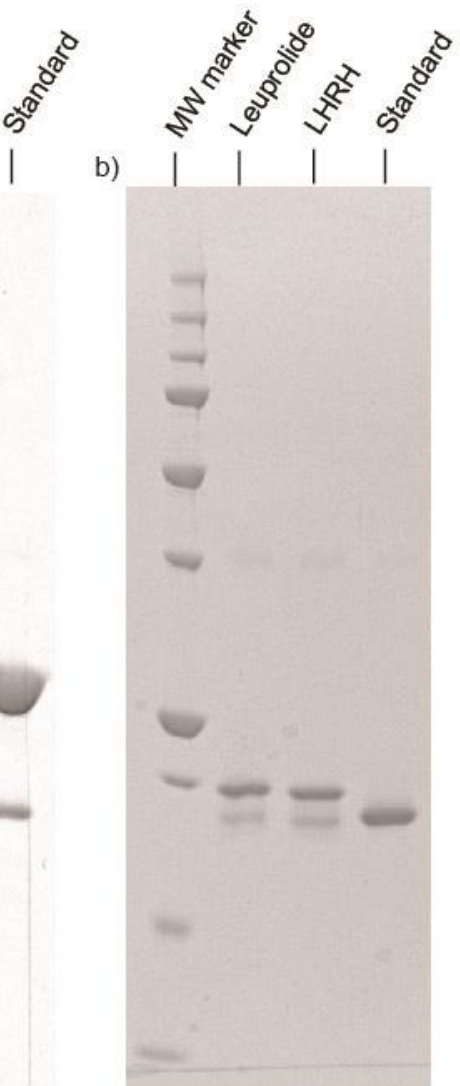

Figure S14. Coomassie gels of the conjugation of T4L-boronic acid to pyroglutamate-histidine GFP (left) and peptides leuprolide and LHRH (right). 
T4L-GFP conjugation with excess T4L-BOH
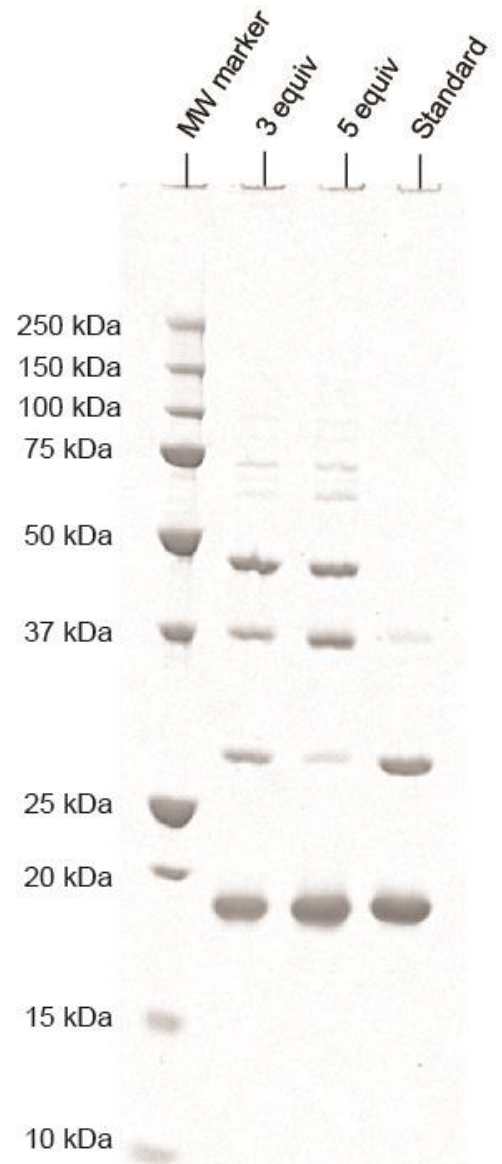

Figure S15. Comassie gel of the conjugation of proglutamate-histidine GFP with excess T4L-boronic acid. 
pGluHis-GFP conjugation with sfGFP-vinylBOH
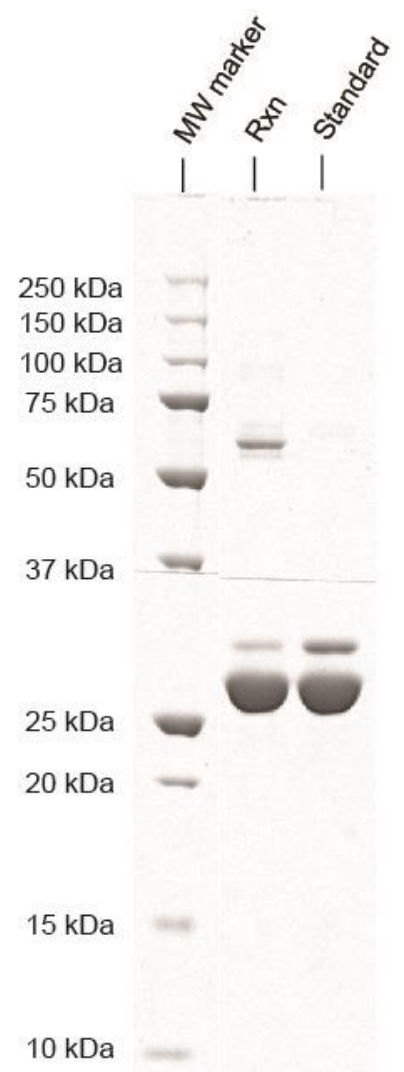

Figure S16. Comassie gel of the conjugation of sfGFP-boronic acid with pyroglutamate-histidine GFP. 


\section{MALDI data for Figure 5}

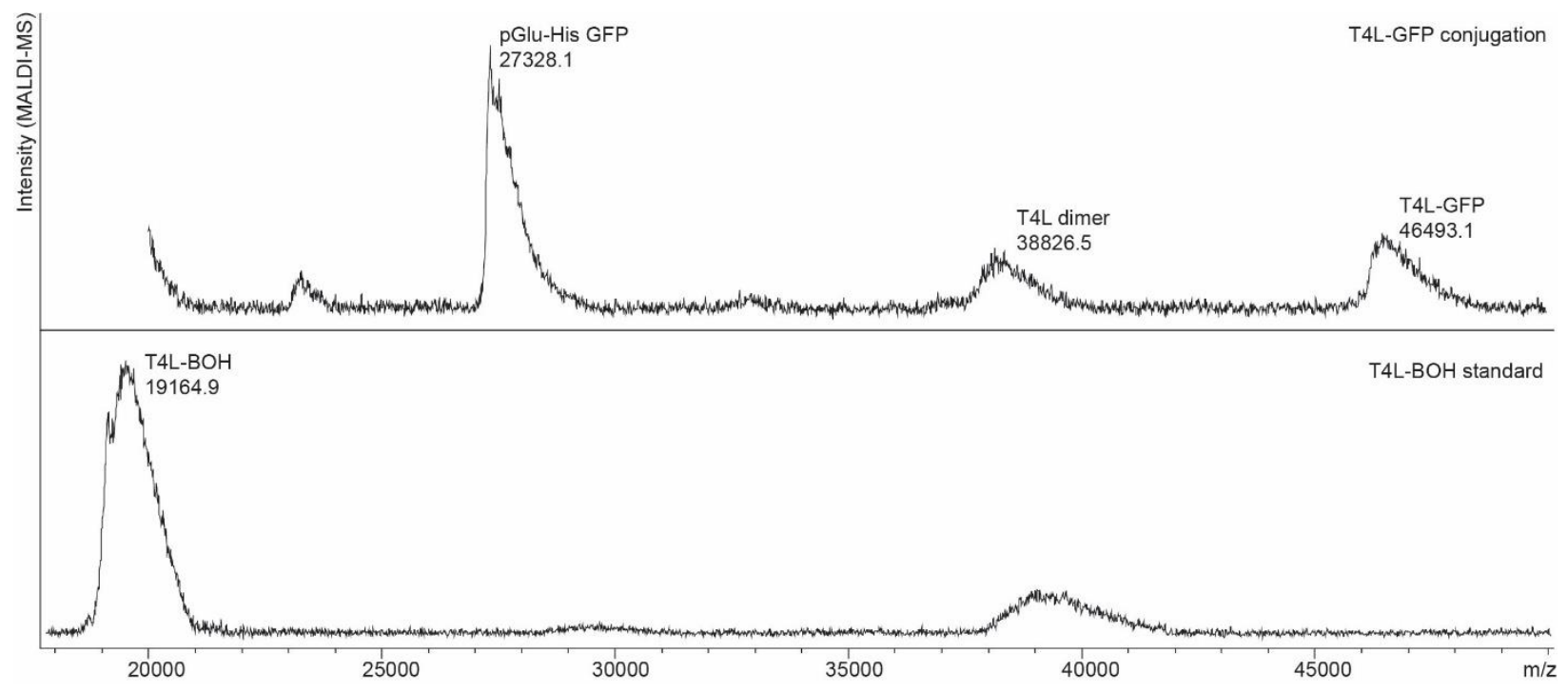

Figure S17. MALDI-MS spectra of conjugation of excess T4L-boronic acid with pyroglutamate-histidine GFP. 


\section{Experimental Procedures}

\section{Boronic Acid Reactivity with Copper(II) and Nickel(II)}

The reagent $N$-acetylcysteine $(0.8 \mu \mathrm{L}, 25 \mathrm{mM}$ in DMSO) and boronic acid (4.0 $\mu \mathrm{L}, 50 \mathrm{mM}$ in DMSO) were added to NMM buffer $(94 \mu \mathrm{L}, 10 \mathrm{mM}, \mathrm{pH} 7.5)$. A $50-\mu \mathrm{L}$ aliquot was removed and to it was added either 2-amino- $N, N$-dimethylbenzenesulfonamide (4 mM stock in DMSO) or angiotensin I (2.5 $\mathrm{mM}$ in $\mathrm{MQ} \mathrm{H}_{2} \mathrm{O}$ ) $(1 \mu \mathrm{L})$ as an internal standard. The mixture was used as the 0 time point injection. To the remaining $49 \mu \mathrm{L}$ was added either $\mathrm{Ni}(\mathrm{OAc})_{2}$ or $\mathrm{Cu}(\mathrm{OAc})_{2}(1 \mu \mathrm{L}, 50 \mathrm{mM})$. The reaction mixture was incubated at $37^{\circ} \mathrm{C}$ for $30 \mathrm{~min}$. The reaction was quenched with EDTA $(1 \mu \mathrm{L}, 100 \mathrm{mM})$ and $1 \mu \mathrm{L}$ of an internal standard was added. Afterwards, the crude reaction mixture was subjected to RP-HPLC analysis.

\section{Vinyl and arylboronic acid stability in nickel(II)-mediated arylation of $\mathrm{N}$-acetylcysteine}

To an NMR tube was added $N$-acetylcysteine $\left(0.5 \mu \mathrm{L}, 250 \mathrm{mM}\right.$ in DMSO- $\left.d_{6}\right)$, 2-nitroboronic acid (6 $\mu \mathrm{L}$, $200 \mathrm{mM}$ in DMSO- $\left.d_{6}\right)$, boronic acid reagent $\mathbf{2 k}$, $\mathbf{2 1}$, or $\mathbf{2} \mathbf{m}\left(6 \mu \mathrm{L}, 200 \mathrm{mM}\right.$ in DMSO- $\left.d_{6}\right), \mathrm{D}_{2} \mathrm{O}(90 \mu \mathrm{L})$, DMF internal standard ( $1 \mu \mathrm{L}, 1.2 \mathrm{M}$ aq. soln.), and NMM buffer $(490.5 \mu \mathrm{L}, 10 \mathrm{mM}, \mathrm{pH} 7.5)$. A 0 min ${ }^{1} \mathrm{H}$ NMR was taken, after which $\mathrm{Ni}(\mathrm{OAc})_{2}\left(6 \mu \mathrm{L}, 100 \mathrm{mM}\right.$ in $\left.\mathrm{MQ} \mathrm{H}_{2} \mathrm{O}\right)$ was added and the reaction mixture was incubated for $30 \mathrm{~min}$ at $37{ }^{\circ} \mathrm{C}$. After the reaction, a $30 \mathrm{~min}{ }^{1} \mathrm{H}$ NMR spectrum was taken. The conversion of boronic acid reagent was determined by comparing the indicated proton integrals to that of the DMF peak at $7.92 \mathrm{ppm}(1 \mathrm{H})$.

\section{Preparation of pEHPGC peptide}

Peptides were synthesized manually using standard solid-phase Fmoc protocols. ${ }^{4}$ After the piperidine deprotection of glycine, TRH (thyrotropin-releasing hormone, free acid) was coupled to the free $\mathrm{N}$-terminus on resin under standard SPPS conditions. The reaction mixture was purified by reverse-phase HPLC (10$30 \% \mathrm{MeCN}$ over $22 \mathrm{~min})$. ESI-MS: calcd for $[\mathrm{M}+\mathrm{H}]^{+}$523.2, found 523.2.

\section{Preparation of 6}

pEHPGC peptide (5) $(5.22 \mathrm{mg}, 0.01 \mathrm{mmol})$ was incubated with TCEP (3.0 $\mathrm{mg}, 0.012 \mathrm{mmol})$ in NMM buffer $(10 \mathrm{mM}, \mathrm{pH} 7.5,13.5 \mathrm{~mL})$ at $37^{\circ} \mathrm{C}$ for $30 \mathrm{~min}$. A solution of bis-(boronic acid) $2 \mathrm{n}(8.52 \mathrm{mg}, 0.02$ $\mathrm{mmol})$ in DMSO $(1.5 \mathrm{~mL})$ and nickel(II) acetate tetrahydrate $(3.73 \mathrm{mg}, 0.015 \mathrm{mmol})$ were then added to the reaction mixture and the resulting solution was stirred at $37{ }^{\circ} \mathrm{C}$ for $5 \mathrm{~h}$. After quenched with EDTA (14.6 $\mathrm{mg}, 0.05 \mathrm{mmol}$ ), the mixture was concentrated by gentle flow of nitrogen gas and purified by reversephase HPLC (10-35\% MeCN over $20 \mathrm{~min}$ ). Lyophilization of collected fractions gave peptide-boronic acid conjugate $6(2.7 \mathrm{mg}, 30 \%)$ as a white powder. ESI-MS: calcd for $[\mathrm{M}+\mathrm{H}]^{+}$903.3, found 903.3.

\section{Pyroglutamate modification}

Peptide-boronic acid conjugate $6\left(0.5 \mu \mathrm{L}, 10 \mathrm{mM}\right.$ in $\left.\mathrm{H}_{2} \mathrm{O}\right)$ was incubated with copper(II) acetate $(0.5 \mu \mathrm{L}$, $50 \mathrm{mM}$ in $\left.\mathrm{H}_{2} \mathrm{O}\right)$ in NMM buffer $(10 \mathrm{mM}, \mathrm{pH} 7.5,24 \mu \mathrm{L})$ at $\mathrm{rt}$ for $2 \mathrm{~h}$. The reaction was quenched with EDTA $\left(1.0 \mu \mathrm{L}, 100 \mathrm{mM}\right.$ in $\left.\mathrm{H}_{2} \mathrm{O}\right)$ and analyzed by LC-MS without purification.

\section{Preparation of stapled peptide 7}

Peptide-boronic acid conjugate $6(2.3 \mathrm{mg}, 2.5 \mu \mathrm{mol})$ was incubated with cupric acetate monohydrate $(0.3$ $\mathrm{mg}, 1.5 \mu \mathrm{mol})$ in NMM buffer $(10 \mathrm{mM}, \mathrm{pH} 7.5,12.75 \mathrm{~mL})$ at $\mathrm{rt}$ for $5 \mathrm{~h}$. After quenched with EDTA (1.46 $\mathrm{mg}, 5.0 \mu \mathrm{mol})$, the mixture was concentrated by gentle flow of nitrogen gas and purified by reverse-phase 
HPLC (15-35\% MeCN over $20 \mathrm{~min}$ ). Lyophilization of collected fractions gave stapled peptide 7 (1.4 $\mathrm{mg}, 65 \%)$ as a white powder. ESI-MS: calcd for $[\mathrm{M}+\mathrm{H}]^{+}$857.3, found 857.3.

\section{Modification of single-cys proteins T4L and sfGFP with desthiobiotin-bis-boronic acid 20}

Cys-protein (final conc. $20 \mu \mathrm{M}$ ) was incubated with TCEP $\left(9.1 \mu \mathrm{L}, 22 \mathrm{mM}\right.$ in $\mathrm{H}_{2} \mathrm{O}$ ) in NMM buffer (final vol. $1 \mathrm{~mL}, 50 \mathrm{mM}, \mathrm{pH} 7.5)$ at $37^{\circ} \mathrm{C}$ for $30 \mathrm{~min}$. Desthiobiotin bis-boronic acid $2 \mathrm{o}(8 \mu \mathrm{L}, 25 \mathrm{mM}$ in DMSO), $\mathrm{Ni}(\mathrm{OAc})_{2}\left(8 \mu \mathrm{L}, 50 \mathrm{mM}\right.$ in $\left.\mathrm{H}_{2} \mathrm{O}\right)$, and 6,6'-dimethyl-2,2'-bipyridine (8 $\mu \mathrm{L}, 50 \mathrm{mM}$ in DMSO$)$ were added and the reaction was incubated at $37^{\circ} \mathrm{C}$ for $30 \mathrm{~min}$. The reaction was quenched with EDTA ( $2 \mu \mathrm{L}, 1 \mathrm{M}$ in $\mathrm{H}_{2} \mathrm{O}$ ) and modified protein was purified according to the procedure in "Pulldown of desthiobiotin-modified Cys proteins".

\section{Pulldown of desthiobiotin-modified Cys proteins}

Cys proteins were modified with $\mathbf{2 0}$ according to the general procedure. After quenching the reaction with EDTA, excess small molecules were removed by PD-10 desalting column eluting with NMM buffer (10 $\mathrm{mM}, \mathrm{pH}$ 7.5). The obtained protein soln was directly loaded onto streptavidin beads $(0.1 \mathrm{~mL})$ preequilibrated with NMM buffer. The suspension was shaken at $\mathrm{rt}$ for $1 \mathrm{~h}$, the supernatant was removed, and the beads were washed $2 \times 1 \mathrm{~mL}$ with NMM buffer $(10 \mathrm{mM}, 150 \mathrm{mM} \mathrm{NaCl}, \mathrm{pH} 7.5)$. The beads were incubated with $0.5 \mathrm{~mL}$ elution buffer (10 mM NMM, $5 \mathrm{mM}$ biotin, $50 \mathrm{mM} \mathrm{NaCl}$, pH 7.5) at rt overnight. The obtained soln were buffer exchanged and concentrated into NMM buffer ( $50 \mathrm{mM}, \mathrm{pH} 7.5)$ by ultrafiltration (Amicon Ultra $0.5 \mathrm{~mL} 10 \mathrm{kDa} \mathrm{MWCO}$ ) and stored in $-20{ }^{\circ} \mathrm{C}$.

\section{Peptide-protein conjugation}

pGlu-His-peptide $\left(1.2 \mu \mathrm{L}, 5 \mathrm{mM}\right.$ in $\left.\mathrm{H}_{2} \mathrm{O}\right)$ was incubated with T4L-boronic acid $(1.36 \mu \mathrm{L}, 147 \mu \mathrm{M}$ in NMM buffer) and copper(II) acetate $\left(0.6 \mu \mathrm{L}, 20 \mathrm{mM}\right.$ in $\left.\mathrm{H}_{2} \mathrm{O}\right)$ in NMM buffer $(6.84 \mu \mathrm{L}, 50 \mathrm{mM}, \mathrm{pH} 7.5)$

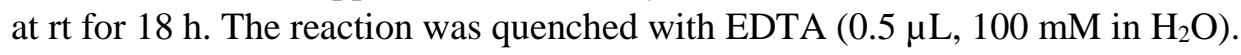

\section{Protein-protein conjugation}

Vinyl boronic acid-labeled protein (final conc. $10 \mu \mathrm{M}$ ) was incubated with pGlu-His-protein (final conc. $50 \mu \mathrm{M}$ ) and copper(II) acetate (final conc. $0.25 \mathrm{mM}$ ) in NMM buffer (50 mM, $150 \mathrm{mM} \mathrm{NaCl}, \mathrm{pH} 7.5$, final vol. $10 \mathrm{uL}$ ) at $\mathrm{rt}$ for $18 \mathrm{~h}$. The reaction was quenched with EDTA (final conc. $5 \mathrm{mM}$ ).

\section{Gel densitometry measurements}

Conversions for protein conjugation reactions were determined by gel densitometry using ImageJ. Protein bands from imaged PAGE gels were converted into density using ImageJ's plot lanes feature. Conversion was measured by dividing the density of the conjugated protein band by the total density of both the conjugated protein band and unconjugated protein band. 


\section{Organic Synthesis}

\section{Preparation of bis-(boronic acid) 2n}
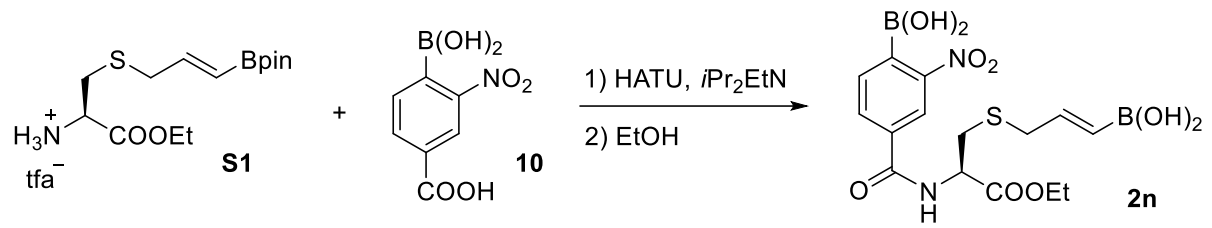

4-Carboxy-2-nitrophenylboronic acid (10) $(21.1 \mathrm{mg}, 0.10 \mathrm{mmol})$ and HATU (53.2 $\mathrm{mg}, 0.14 \mathrm{mmol})$ were dissolved in DMF $(0.5 \mathrm{~mL})$. Diisopropylethylamine $(69.7 \mu \mathrm{L}, 0.40 \mathrm{mmol})$ was added at $0{ }^{\circ} \mathrm{C}$, and the mixture was stirred at $\mathrm{rt}$ for $10 \mathrm{~min}$. The soln was cooled by ice cold bath and added to oil of S1·tfa (35.6 $\mathrm{mg}, 0.083 \mathrm{mmol}$ ) in a 4-mL vial. The mixture was stirred at $\mathrm{rt}$ for $4 \mathrm{~h}$, and all of the volatiles were removed by gentle flow of nitrogen gas. EtOH $(2 \mathrm{~mL})$ was added to the resulting oil, and the soln was stirred at $\mathrm{rt}$ overnight for alcoholysis of the pinacol ester. After addition of water $(1 \mathrm{~mL})$, the mixture was concentrated by gentle flow of nitrogen gas and purified by reverse-phase HPLC (10-80\% MeCN over $22 \mathrm{~min}$ ). Lyophilization of collected fractions gave $\mathbf{2 n}(10.6 \mathrm{mg}, 25 \%)$ as an amorphous solid. ${ }^{1} \mathrm{H}$ NMR (600 MHz, $\left.\mathrm{CD}_{3} \mathrm{CN}\right) \delta 8.54(\mathrm{~m}, 1 \mathrm{H}), 8.13(\mathrm{~m}, 1 \mathrm{H}), 7.69-7.63(\mathrm{~m}, 2 \mathrm{H}), 6.35(\mathrm{dt}, J=17.7,7.0 \mathrm{~Hz}, 1 \mathrm{H}), 5.47(\mathrm{~d}, J=$ $17.7 \mathrm{~Hz}, 1 \mathrm{H}), 4.75(\mathrm{~m}, 1 \mathrm{H}), 4.18(\mathrm{q}, J=7.1 \mathrm{~Hz}, 2 \mathrm{H}), 3.25(\mathrm{~m}, 2 \mathrm{H}), 3.04(\mathrm{~m}, 1 \mathrm{H}), 2.88(\mathrm{~m}, 1 \mathrm{H}), 1.25(\mathrm{t}, J=$ $7.1 \mathrm{~Hz}, 3 \mathrm{H}) .{ }^{13} \mathrm{C}$ NMR $\left(151 \mathrm{MHz}, \mathrm{CD}_{3} \mathrm{CN}\right) \delta 171.4,166.1,151.2,146.0,135.8,133.6,133.3,122.5,62.4$, 53.6, 36.7, 32.6, 14.4. HRMS calcd for $\mathrm{C}_{15} \mathrm{H}_{20} \mathrm{~B}_{2} \mathrm{~N}_{2} \mathrm{O}_{9} \mathrm{~S}[\mathrm{M}+\mathrm{H}]^{+} 427.1148$, found 427.1141 . ${ }^{13} \mathrm{C}-\mathrm{B}$ not observed due to quadrupolar relaxation.,

\section{Preparation of Amino-nitrophenyl boronic acid 11}

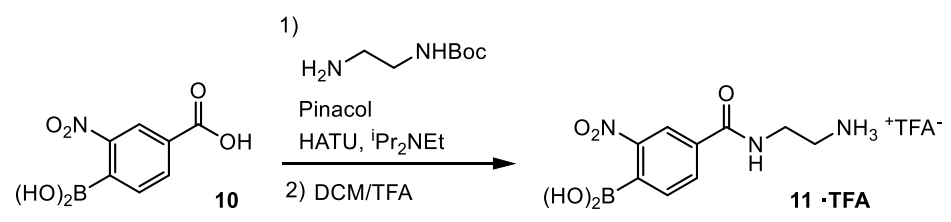

4-Carboxy-2-nitrophenylboronic acid 10 (150 mg, $0.710 \mathrm{mmol})$ and HATU (271 mg, $0.710 \mathrm{mmol})$ were dissolved in DMF $(800 \mu \mathrm{L})$. Diisopropylethylamine $(371 \mu \mathrm{L}, 2.13 \mathrm{mmol})$ was added at $0{ }^{\circ} \mathrm{C}$ and stirred at $\mathrm{rt}$ for $10 \mathrm{~min}$. N-Boc ethylenediamine $(224 \mu \mathrm{L}, 1.42 \mathrm{mmol})$ and pinacol $(252 \mathrm{mg}, 2.13 \mathrm{mmol})$ were added in one portion at $0{ }^{\circ} \mathrm{C}$ and the soln was stirred at $\mathrm{rt}$ for $5 \mathrm{~h}$. After removal of volatiles by gentle stream of nitrogen gas, the mixture was suspended in ethyl acetate $(10 \mathrm{~mL})$ and washed with sat. $\mathrm{KHSO}_{4}(3 \mathrm{x} 4$ $\mathrm{mL})$, DI $\mathrm{H}_{2} \mathrm{O}(2 \times 4 \mathrm{~mL})$, and brine $(1 \times 10 \mathrm{~mL})$. The organic layer was dried over $\mathrm{MgSO}_{4}$, filtered, and solvent was removed under vacuum to afford the pinacol boronate with residual pinacol as a yellow film. The pinacol boronate $(318 \mathrm{mg}, 0.731 \mathrm{mmol})$ was suspended in $\mathrm{CH}_{2} \mathrm{Cl}_{2}(750 \mu \mathrm{L})$ and TFA $(250 \mu \mathrm{L})$ was added at $0{ }^{\circ} \mathrm{C}$ and the soln was stirred at $\mathrm{rt} 3 \mathrm{~h}$. Toluene $(1.8 \mathrm{~mL})$ was added, and all volatiles removed by gentle stream of nitrogen gas. The solid was dissolved in $0.1 \%$ TFA $(10 \mathrm{~mL})$, washed with ether $(10 \times 10$ $\mathrm{mL})$, and lyophilized to afford $\mathbf{1 1} \cdot \mathbf{t f a}$ contaminated with traces $(7 \%)$ of pinacol as a yellow amorphous solid (128 mg, 45\%, 2 steps). ${ }^{1} \mathrm{H}$ NMR (600 MHz, $\left.\mathrm{D}_{2} \mathrm{O}\right): \delta 8.56(\mathrm{~s}, 1 \mathrm{H}), 8.10(\mathrm{~d}, J=7.7 \mathrm{~Hz}, 1 \mathrm{H}), 7.70$ (d, $J=7.7 \mathrm{~Hz}, 1 \mathrm{H}), 3.71(\mathrm{t}, J=6.0 \mathrm{~Hz}, 2 \mathrm{H}), 3.26(\mathrm{t}, J=6.0 \mathrm{~Hz}, 2 \mathrm{H}) .{ }^{13} \mathrm{C}$ NMR $\left(151 \mathrm{MHz}, \mathrm{D}_{2} \mathrm{O}\right) \delta 168.9$, $149.5,136.9,134.7,133.0,132.5,121.9,75.6,39.2$. HRMS calcd for $\mathrm{C}_{9} \mathrm{H}_{12} \mathrm{BN}_{3} \mathrm{O}_{5}[\mathrm{M}+\mathrm{H}]^{+}:$: 254.0943, found 254.0944 . 


\section{Preparation of Desthiobiotin bis-boronic acid 2o}

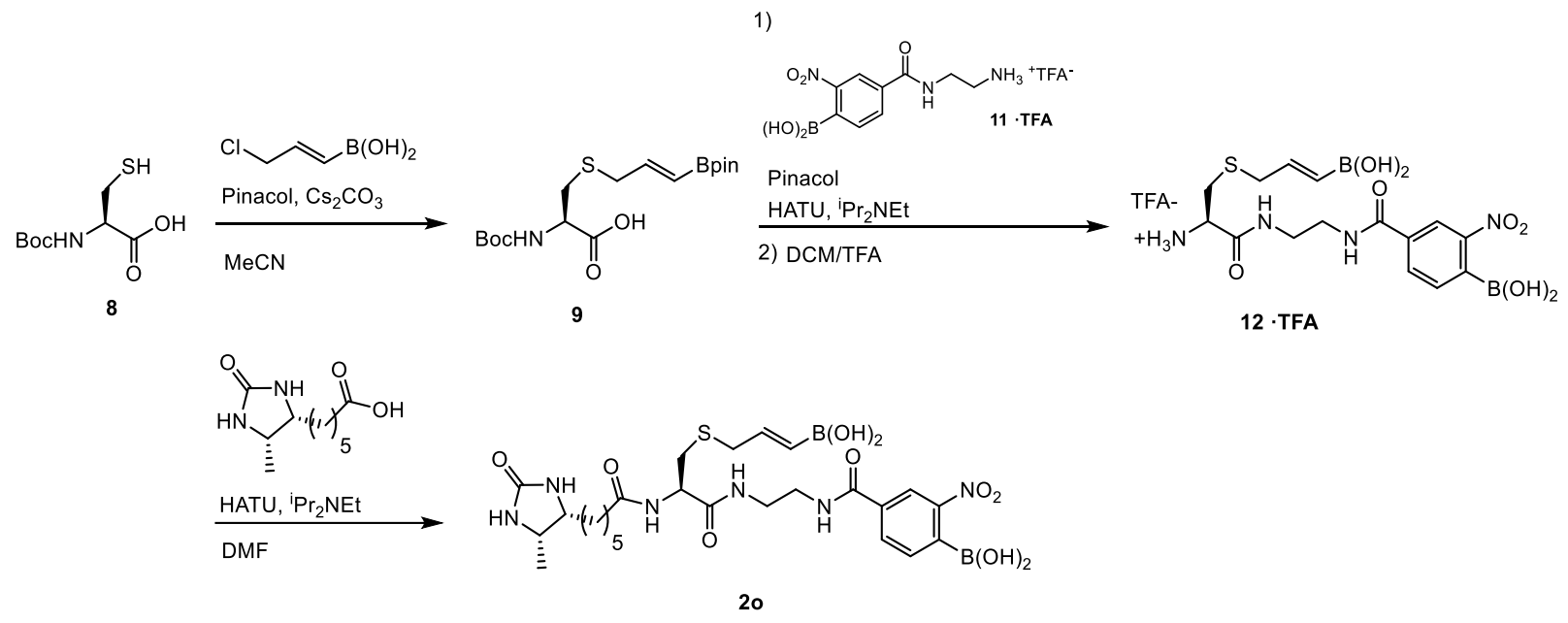

Boc-L-cysteine 8 (244 mg, $1.09 \mathrm{mmol}$ ), trans-2-chloromethylvinylboronic acid (270 mg, $2.17 \mathrm{mmol}$ ), cesium carbonate (1060 mg, $3.26 \mathrm{mmol}$ ), and pinacol (398 mg, $3.26 \mathrm{mmol}$ ) were suspended in MeCN $(3.5 \mathrm{~mL})$, and the reaction mixture was stirred vigorously at $\mathrm{rt}$ for $5 \mathrm{~h}$. After removal of volatiles by gentle stream of nitrogen gas, the mixture was suspended in ethyl acetate $(30 \mathrm{~mL})$ and washed with $10 \%$ citrate (42 mL), $\mathrm{H}_{2} \mathrm{O}(3 \times 24 \mathrm{~mL})$, and brine $(24 \mathrm{~mL})$. The organic layer was dried over $\mathrm{MgSO}_{4}$, filtered, and solvent was removed under vacuum to afford 9 as a yellow oil (443 mg). The material was used in the next steps without further purification. Partial characterization: ${ }^{1} \mathrm{H}$ NMR $\left(600 \mathrm{MHz}, \mathrm{CDCl}_{3}\right): \delta 6.50(\mathrm{~m}$, $1 \mathrm{H}), 5.53(\mathrm{~d}, J=17.7 \mathrm{~Hz}, 1 \mathrm{H}), 4.5(\mathrm{~s}, 1 \mathrm{H}), 3.21(\mathrm{~d}, J=7.0 \mathrm{~Hz}, 2 \mathrm{H}), 2.95(\mathrm{~m}, 1 \mathrm{H}), 2.88(\mathrm{~m}, 1 \mathrm{H}), 1.45(\mathrm{~s}$, 9H), $1.27(\mathrm{~s}, 12 \mathrm{H}) .{ }^{13} \mathrm{C} \mathrm{NMR}\left(151 \mathrm{MHz}, \mathrm{CDCl}_{3}\right): \delta 171.5,155.6,147.8,146.8,83.6,80.5,60.6,36.8$, 33.0, 28.4, 24.8. ESI-MS calcd for $\mathrm{C}_{17} \mathrm{H}_{30} \mathrm{BNO}_{6} \mathrm{~S}[\mathrm{M}-\mathrm{H}]:$ : 386.2, found 386.2.

9 (70.3 mg, $0.182 \mathrm{mmol})$ and HATU (69.3 mg, $0.182 \mathrm{mmol})$ were dissolved in DMF $(300 \mu \mathrm{L})$. Diisopropylethylamine $(95 \mu \mathrm{L}, 0.546 \mathrm{mmol})$ was added at $0{ }^{\circ} \mathrm{C}$ and stirred at $\mathrm{rt}$ for $10 \mathrm{~min}$. 11 $\cdot$ tfa (107 $\mathrm{mg}, 0.291 \mathrm{mmol})$ in DMF $(107 \mu \mathrm{L})$ and pinacol $(65 \mathrm{mg}, 0.546 \mathrm{mmol})$ were added in one portion at $0{ }^{\circ} \mathrm{C}$ and the soln was stirred at $\mathrm{rt}$ for $3 \mathrm{~h}$. After removal of volatiles by gentle stream of nitrogen gas, the mixture was suspended in ethyl acetate $(7 \mathrm{~mL})$ and washed with sat. $\mathrm{KHSO}_{4}(3 \times 3 \mathrm{~mL}), \mathrm{H}_{2} \mathrm{O}(2 \times 4 \mathrm{~mL})$, and brine $(1 \times 7 \mathrm{~mL})$. The organic layer was dried over $\mathrm{MgSO}_{4}$, filtered, and solvent was removed under vacuum. The pinacol boronate $(87.3 \mathrm{mg}, 0.121 \mathrm{mmol})$ was suspended in $\mathrm{CH}_{2} \mathrm{Cl}_{2}(750 \mu \mathrm{L})$ and TFA $(250$ $\mu \mathrm{L})$ was added at $0{ }^{\circ} \mathrm{C}$ and the soln was stirred at $\mathrm{rt} 3 \mathrm{~h}$. Toluene $(1.7 \mathrm{~mL})$ was added, and all volatiles removed by gentle stream of nitrogen gas. The solid was dissolved in $0.1 \%$ TFA $(10 \mathrm{~mL})$, washed with ether $(8 \times 8 \mathrm{~mL})$, and lypholized to afford $\mathbf{1 2} \cdot \mathbf{t f a}$ as an orange film $(68 \mathrm{mg})$. The material was used in the next steps without further purification. Partial characterization: ${ }^{1} \mathrm{H}$ NMR $\left(600 \mathrm{MHz}, \mathrm{D}_{2} \mathrm{O}\right): \delta 8.43(\mathrm{~s}, 1 \mathrm{H})$, $7.99(\mathrm{dd}, J=7.7,1.6 \mathrm{~Hz}, 1 \mathrm{H}), 7.61(\mathrm{~d}, J=7.7 \mathrm{~Hz}, 1 \mathrm{H}), 6.27(\mathrm{dt}, J=17.8,6.7 \mathrm{~Hz}, 1 \mathrm{H}), 5.43(\mathrm{~d}, J=17.8$ $\mathrm{Hz}, 1 \mathrm{H}), 3.99(\mathrm{t}, J=6.7 \mathrm{~Hz}, 1 \mathrm{H}), 3.50(\mathrm{~m}, 2 \mathrm{H}), 3.27(\mathrm{~m}, 1 \mathrm{H}), 3.16(\mathrm{~m}, 1 \mathrm{H}), 3.05(\mathrm{~d}, J=6.3 \mathrm{~Hz}, 2 \mathrm{H})$, 2.73-2.86 (m, 2H). ${ }^{13} \mathrm{C}$ NMR $\left(151 \mathrm{MHz}, \mathrm{D}_{2} \mathrm{O}\right): \delta 172.3,168.5,149.4,144.9,135.2,133.1,132.4,121.8$, 117.2, 115.3, 75.6, 53.1, 52.2, 38.8, 35.3, 30.7. ESI-MS calcd for $\mathrm{C}_{15} \mathrm{H}_{22} \mathrm{~B}_{2} \mathrm{~N}_{4} \mathrm{O}_{8} \mathrm{~S}[\mathrm{M}+\mathrm{H}]^{+}: 441.1$, found 441.2 . 
Desthiobiotin (6 mg, $0.028 \mathrm{mmol})$ and HATU $(10.6 \mathrm{mg}, 0.028 \mathrm{mmol})$ were dissolved in DMF $(50 \mu \mathrm{L})$. Diisopropylethylamine $(14.6 \mu \mathrm{L}, 0.084 \mathrm{mmol})$ was added at $0{ }^{\circ} \mathrm{C}$ and stirred at $\mathrm{rt}$ for $10 \mathrm{~min}$. $\mathbf{1 2} \cdot \mathbf{t f a}(20$ $\mathrm{mg}, 0.036 \mathrm{mmol})$ in DMF $(60 \mu \mathrm{L})$ was added in one portion at $0{ }^{\circ} \mathrm{C}$ and the soln was stirred at $\mathrm{rt}$ for $19 \mathrm{~h}$. After removal of volatiles by gentle stream of nitrogen gas, the mixture was suspended in $0.1 \%$ TFA (2 $\mathrm{mL})$, filtered, and purified by reverse-phase HPLC (10-55\% MeCN over $22 \mathrm{~min})$. The collected fractions were lyophilized to afford $\mathbf{2 0}$ as a white amorphous solid $(8.2 \mathrm{mg}, 12 \%, 4$ steps $) .{ }^{1} \mathrm{H}$ NMR $(600 \mathrm{MHz}$, MeOH- $\left.d_{4}\right): \delta 8.78(\mathrm{~m}, 1 \mathrm{H}), 8.70(\mathrm{~s}, 1 \mathrm{H}), 8.29(\mathrm{~m}, 1 \mathrm{H}), 8.22(\mathrm{~d}, J=7.6 \mathrm{~Hz}, 1 \mathrm{H}), 7.66(\mathrm{~d}, J=7.6 \mathrm{~Hz}, 1 \mathrm{H})$, $6.36(\mathrm{dt}, J=17.4 \mathrm{~Hz}, 1 \mathrm{H}), 5.65(\mathrm{~d}, J=17.4 \mathrm{~Hz}, 1 \mathrm{H}), 4.42(\mathrm{t}, J=7.1 \mathrm{~Hz}, 1 \mathrm{H}), 3.80(\mathrm{~m}, 1 \mathrm{H}), 3.69(\mathrm{q}, J=$ $7.2 \mathrm{~Hz}, 1 \mathrm{H}), 3.56(\mathrm{t}, J=5.7 \mathrm{~Hz}, 2 \mathrm{H}), 3.46(\mathrm{t}, J=5.7 \mathrm{~Hz}, 2 \mathrm{H}), 3.20(\mathrm{~d}, J=7.0 \mathrm{~Hz}, 2 \mathrm{H}), 2.84(\mathrm{~m}, 1 \mathrm{H}), 2.64$ (m, 1H), $2.25(\mathrm{~m}, 2 \mathrm{H}), 1.62(\mathrm{t}, J=7.3 \mathrm{~Hz}, 2 \mathrm{H}), 1.48(\mathrm{t}, J=7.4 \mathrm{~Hz}, 2 \mathrm{H}), 1.32-1.45(\mathrm{~m}, 4 \mathrm{H}), 1.29(\mathrm{~m}, 2 \mathrm{H})$, $1.09(\mathrm{~d}, J=6.4 \mathrm{~Hz}, 3 \mathrm{H}) .{ }^{13} \mathrm{C}$ NMR $\left(151 \mathrm{MHz}, \mathrm{MeOH}-d_{4}\right): \delta 174.9,172.1,166.6,164.8,150.4,145.9$, 136.1, 132.7, 132.0, 121.5, 56.0, 52.9, 51.3, 39.5, 39.0, 35.6, 35.2, 31.8, 29.3, 28.8, 25.7, 25.2, 14.2. HRMS calcd for $\mathrm{C}_{25} \mathrm{H}_{38} \mathrm{~B}_{2} \mathrm{~N}_{6} \mathrm{O}_{10} \mathrm{~S}[\mathrm{M}+\mathrm{H}]^{+}: 637.2629$, found $637.2643 .{ }^{13} \mathrm{C}-\mathrm{B}$ not observed due to quadrupolar relaxation. ${ }^{5,6}$ 


\section{HPLC trace of compound $20(254 \mathrm{~nm})$}

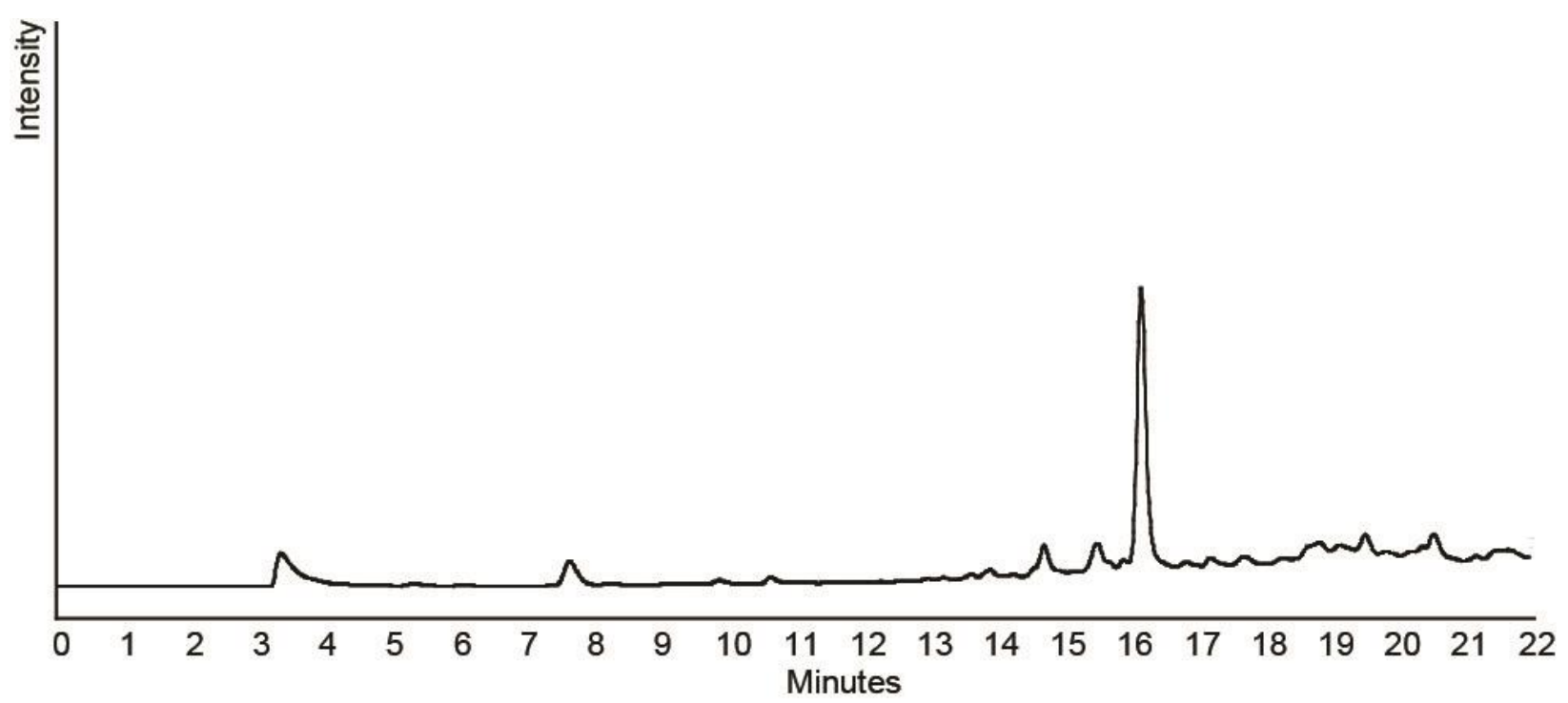

\section{UPLC trace of compound $11(254 \mathrm{~nm})$}

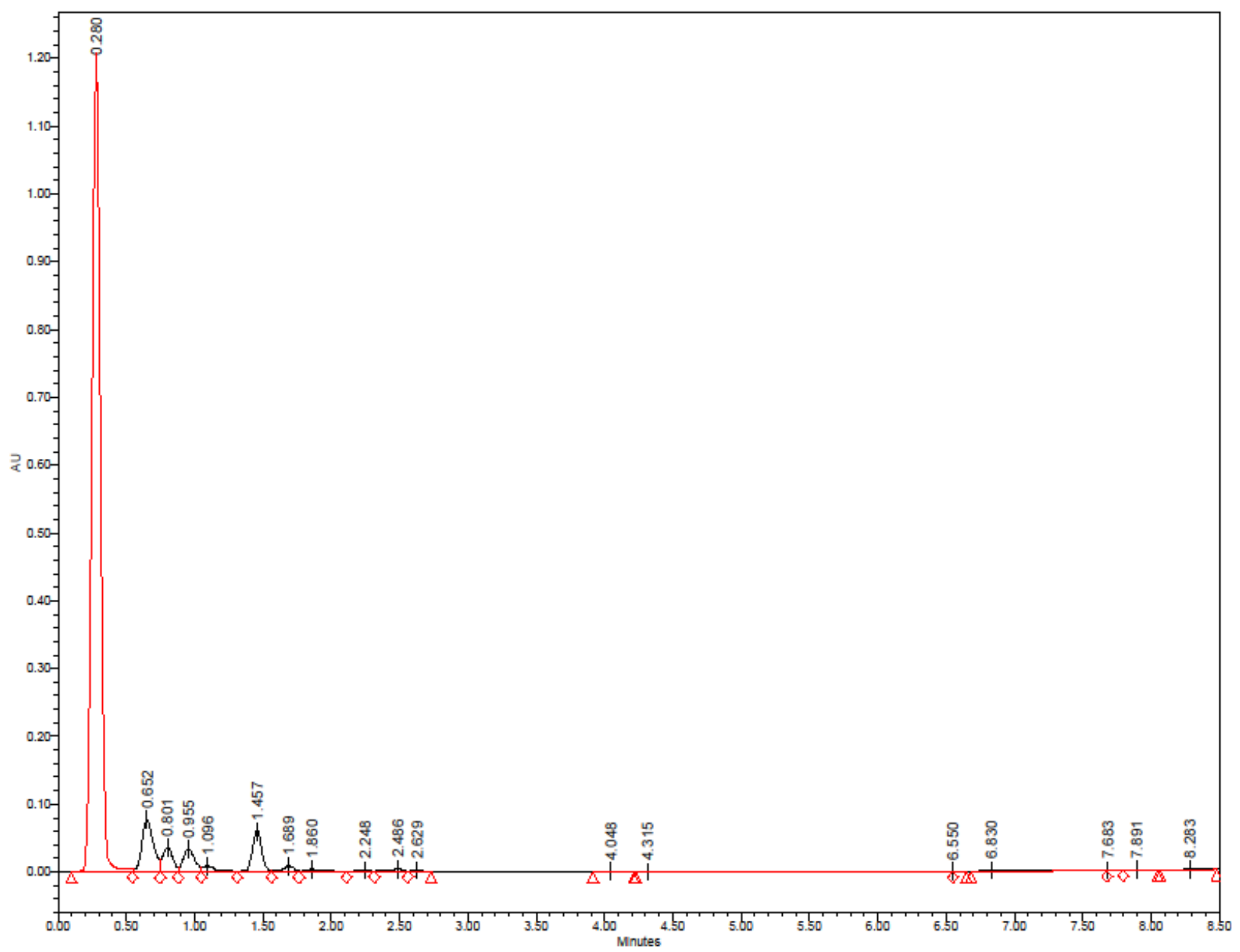




\section{HRMS Spectra of synthesized compounds}

Bis boronic acid (2n)

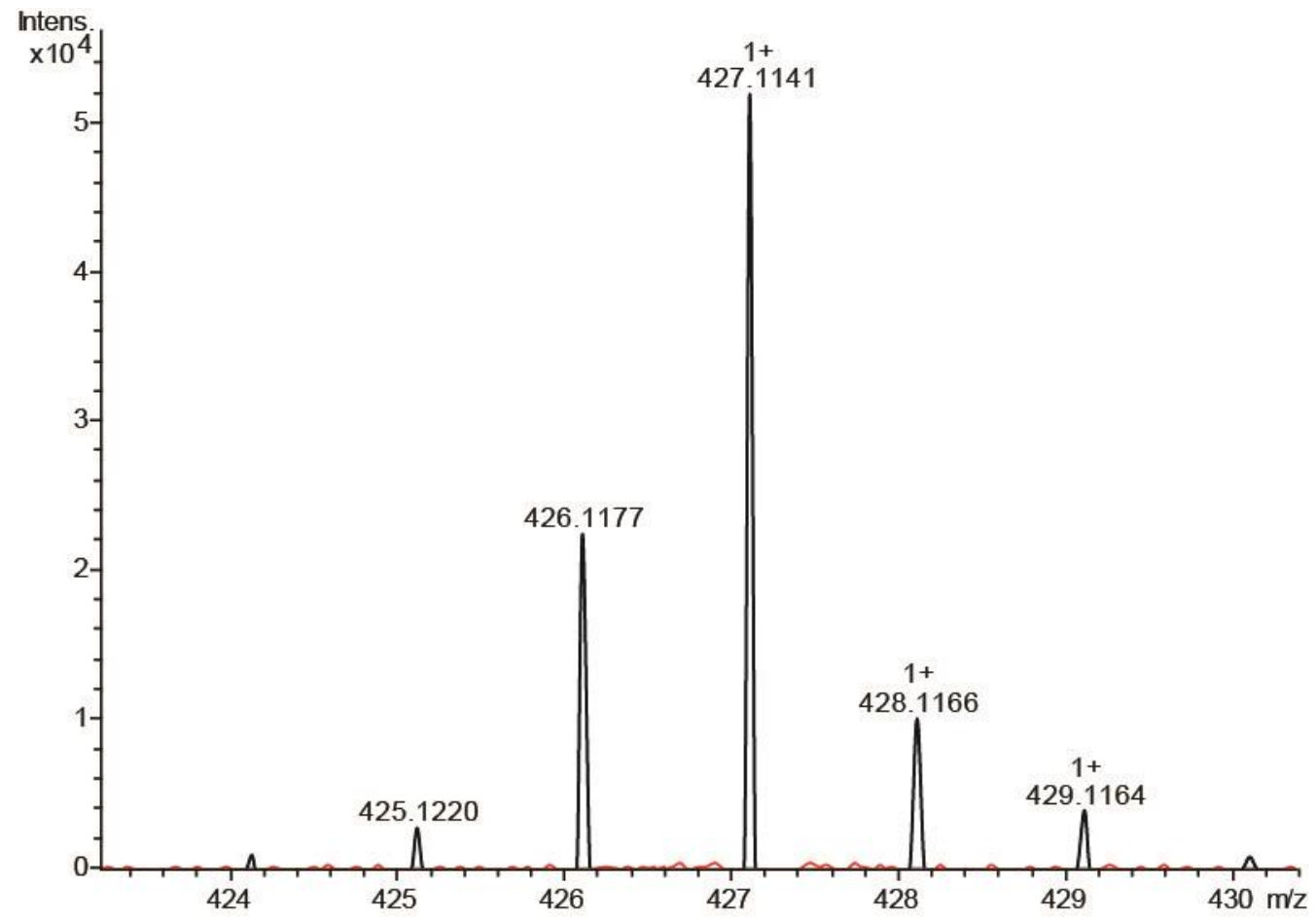

Desthiobiotin bis-boronic acid (2o)

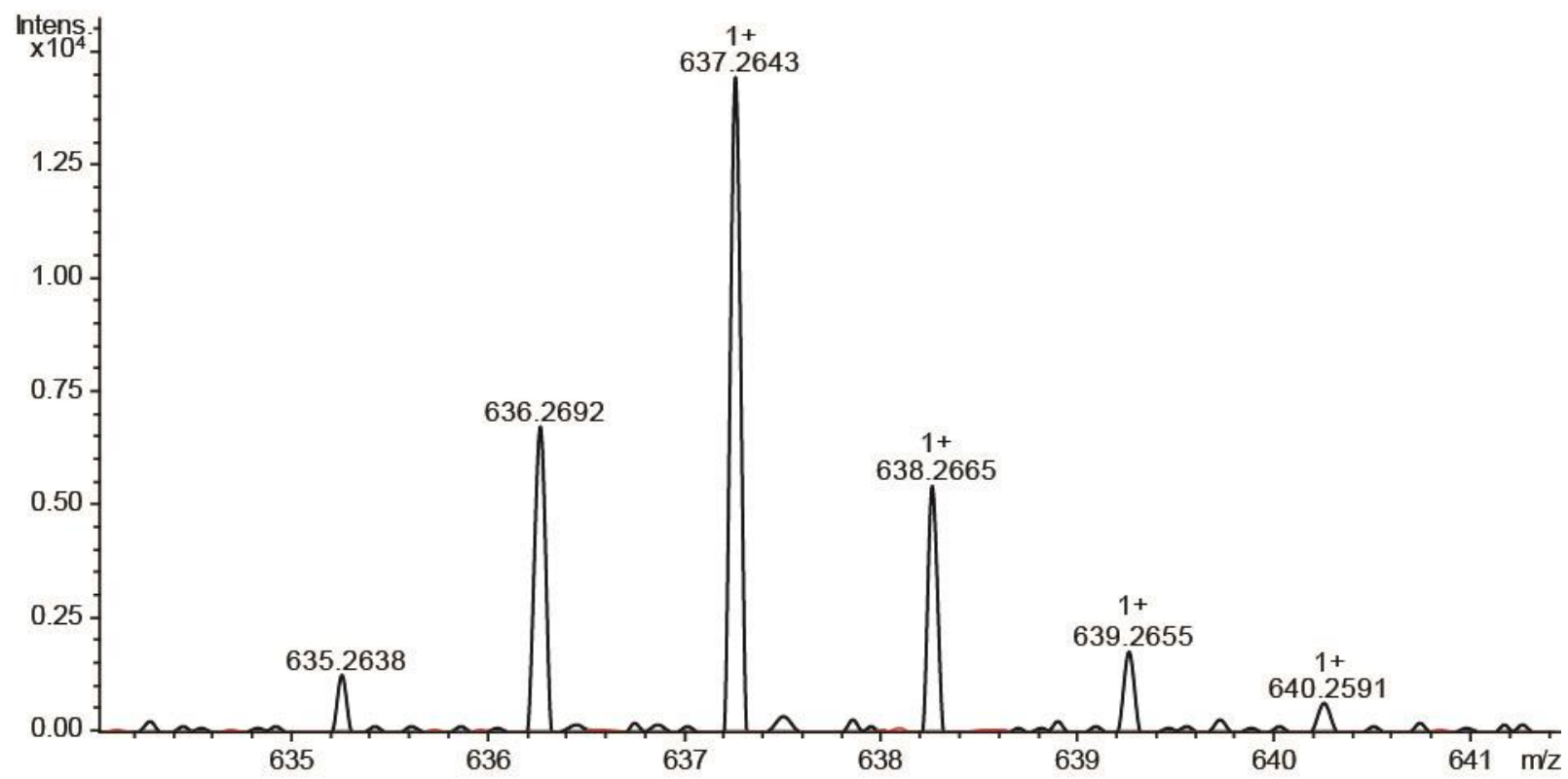


Amino-nitrophenyl boronic acid (11)

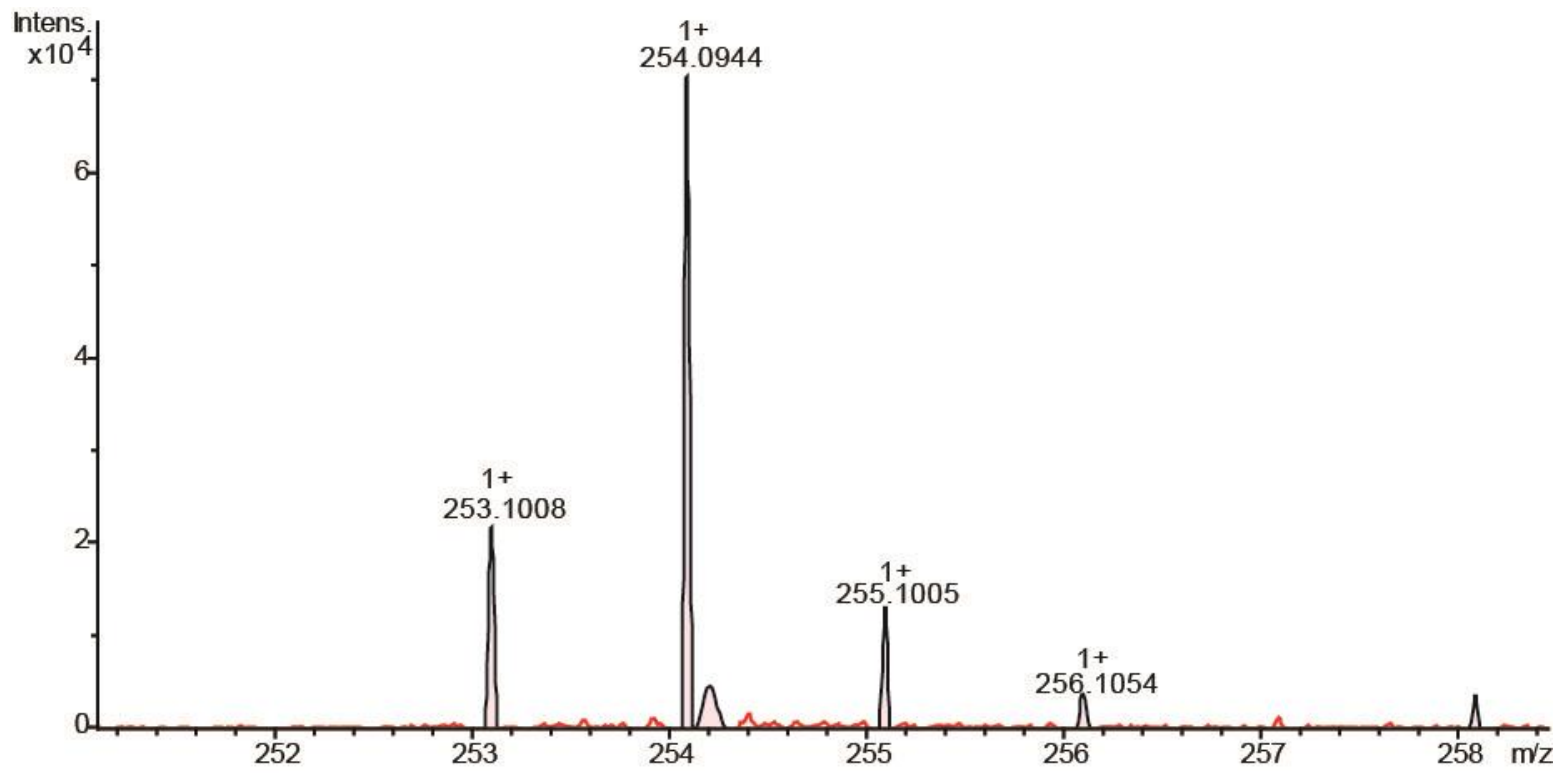


NMR Spectra of synthesized compounds

Bis-boronic acid (2n) ( ${ }^{1} \mathrm{H}$ NMR in $\left.\mathrm{CD}_{3} \mathrm{CN}, 600 \mathrm{MHz}\right)$

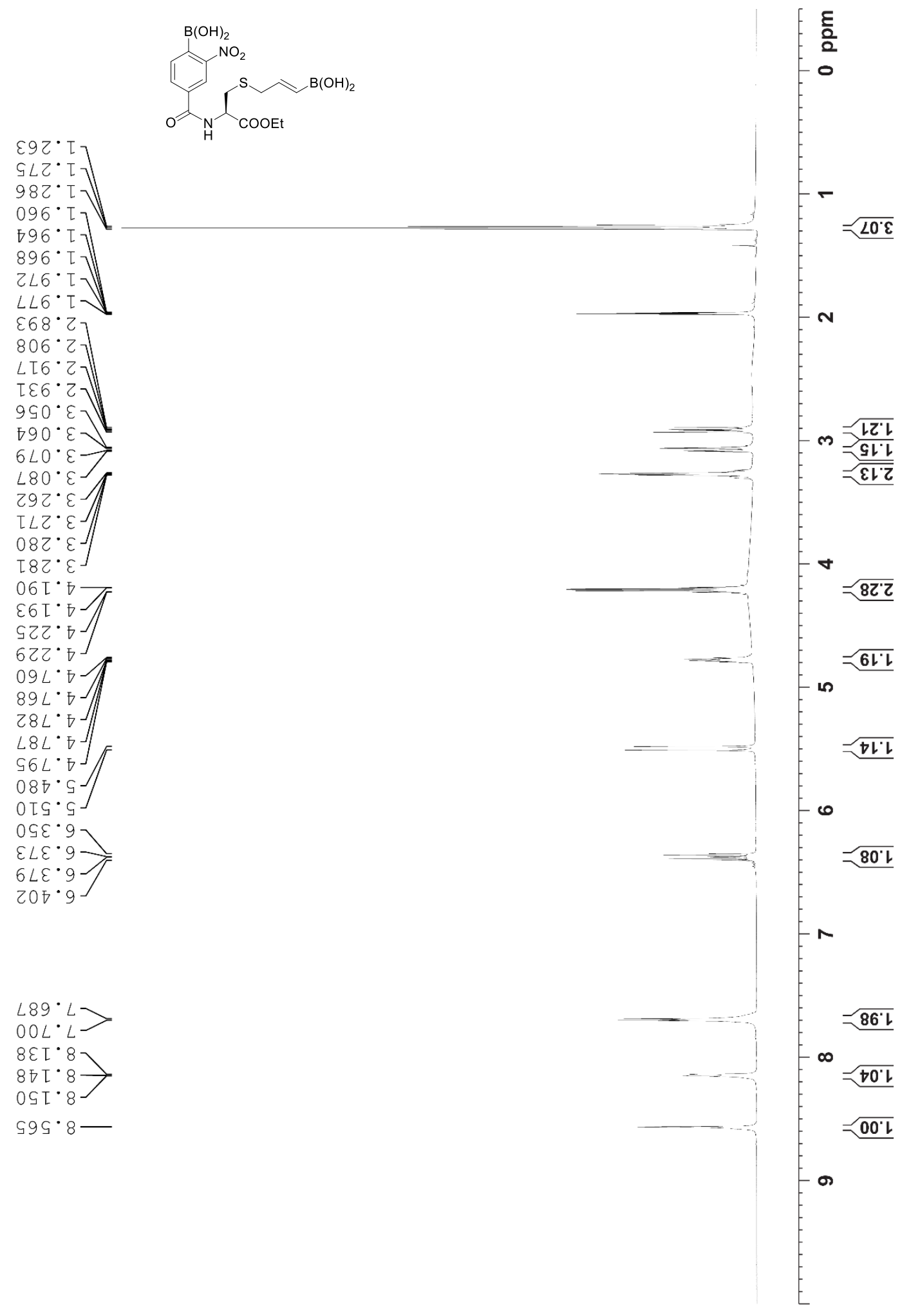




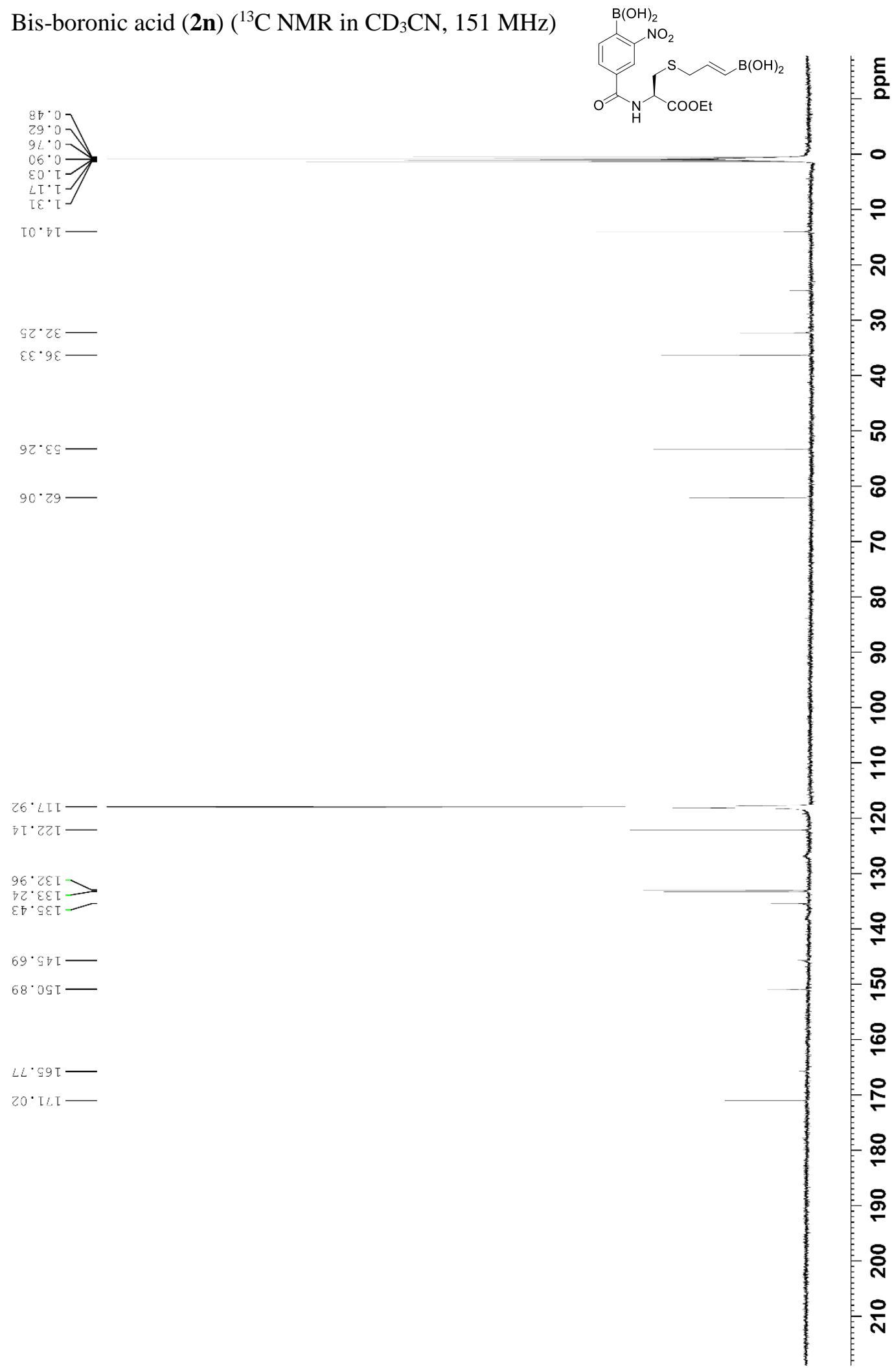


Desthiobiotin bis-boronic acid (2o) $\left({ }^{1} \mathrm{H}\right.$ NMR in MeOD, $\left.600 \mathrm{MHz}\right)$

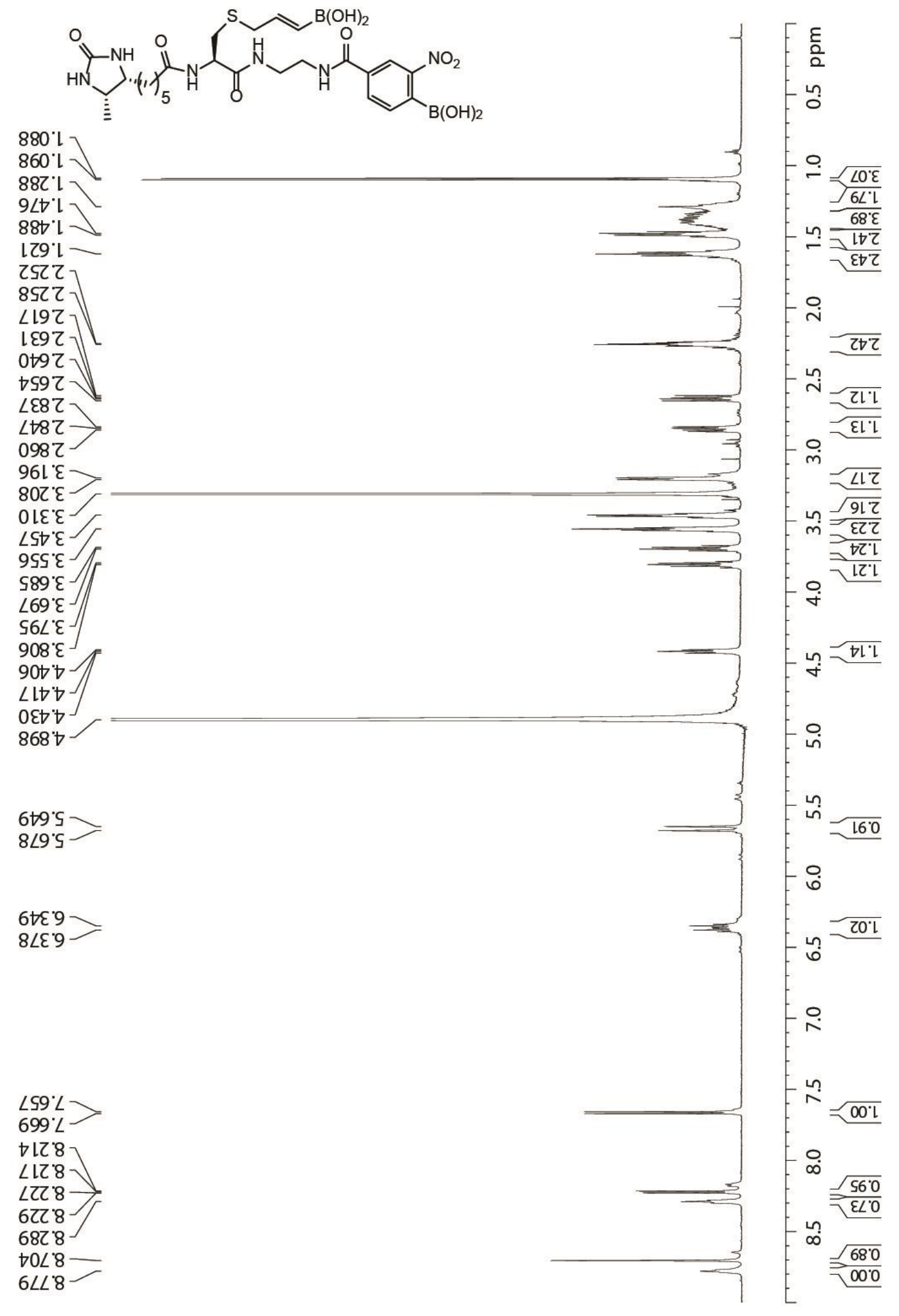


Desthiobiotin bis-boronic acid (2o) $\left({ }^{13} \mathrm{C}\right.$ NMR in MeOD, $\left.151 \mathrm{MHz}\right)$

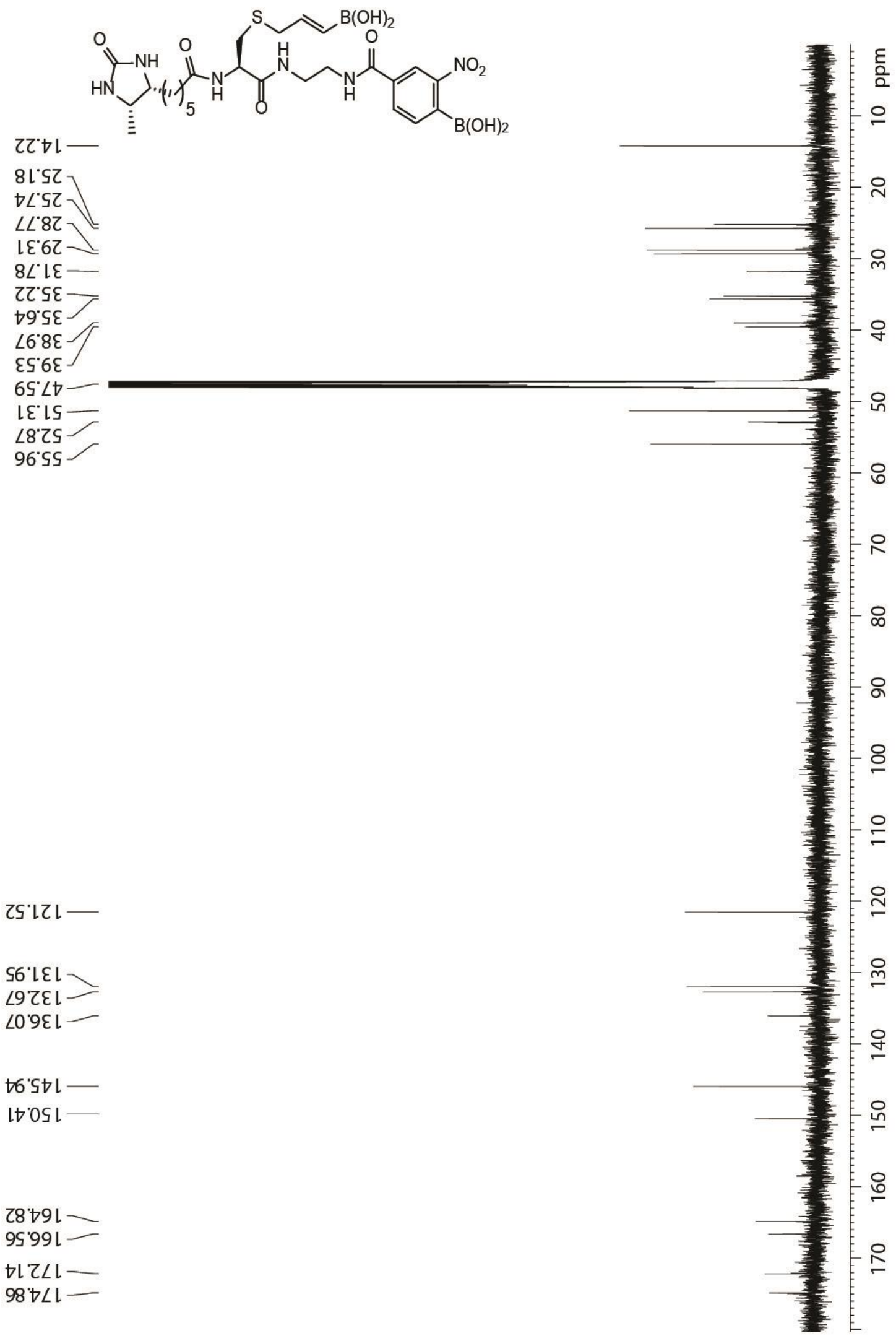


Amino-nitrophenyl boronic acid (11) $\left({ }^{1} \mathrm{H}\right.$ NMR in $\left.\mathrm{D}_{2} \mathrm{O}, 600 \mathrm{MHz}\right)$

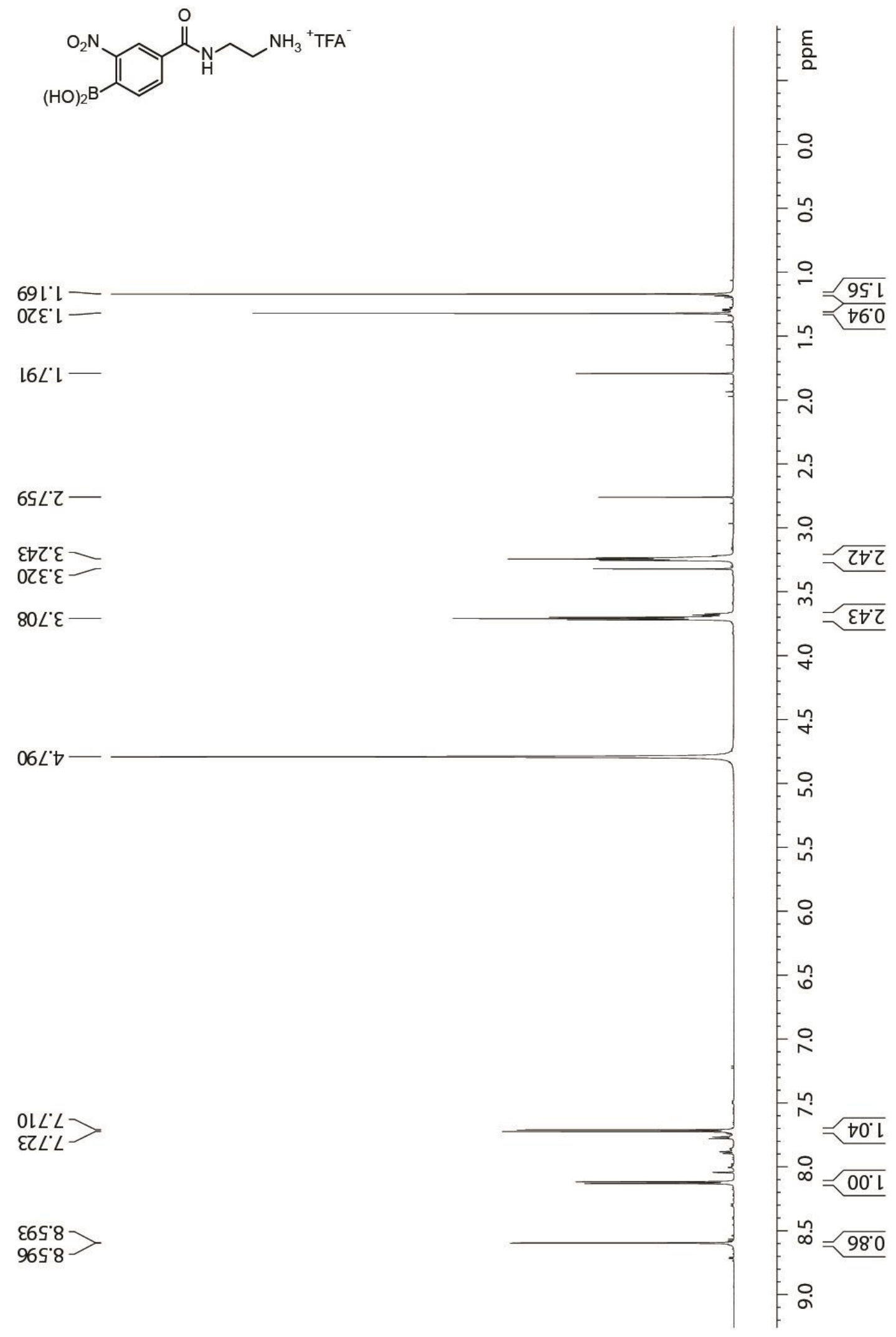




\section{References}

(1) White, C. J.; Bode, J. W. PEGylation and Dimerization of Expressed Proteins under Near Equimolar Conditions with Potassium 2-Pyridyl Acyltrifluoroborates. ACS Cent. Sci. 2018, 4 (2), 197-206.

(2) Ohata, J.; Zeng, Y.; Segatori, L.; Ball, Z. T. A Naturally Encoded Dipeptide Handle for Bioorthogonal Chan-Lam Coupling. Angew. Chem. Int. Ed. 2018, 57 (15), 4015-4019.

(3) Yakhnin, A. V.; Vinokurov, L. M.; Surin, A. K.; Alakhov, Y. B. Green Fluorescent Protein Purification by Organic Extraction. Protein Expr. Purif. 1998, 14 (3), 382-386.

(4) Wellings, D.A.; Atherton, E. Methods Enzymol. Standard Fmoc Protocols. 1997, 289, 44-67.

(5) Hanaya, K.; Miller, M. K.; Ball, Z. T. Nickel(II)-Promoted Amide N-H Arylation of PyroglutamateHistidine with Arylboronic Acid Reagents. Org. Lett. 2019, 21 (7), 2445-2448.

(6) Hanaya, K.; Ohata, J.; Miller, M. K.; Mangubat-Medina, A. E.; Swierczynski, M. J.; Yang, D. Y.;

Rosenthal, R. M.; Ball, Z. T. Rapid nickel(ii)-promoted cysteine $S$-arylation with arylboronic acids.

Chem. Commun. 2019, 55 (19), 2841-2844. 